\title{
Original Paper \\ Myrtaceae from the Atlantic forest subtropical highlands of São Joaquim National Park (Santa Catarina, Brazil)
}

\author{
Mariana de Andrade Wagner ${ }^{1,4}$ \& Pedro Fiaschi ${ }^{2,3}$
}

\begin{abstract}
Studies that address the floristic composition of the Atlantic forest show that Myrtaceae is one of the richest families in number of tree species. In Southern Brazil, Myrtaceae is present mainly in forest formations, such as broadleaf rain forests and broadleaf cloud forests, mixed needle and broadleaf forests (Araucaria forests), and seasonal semi-deciduous forests. The objective of this study was to survey the Myrtaceae of the upper highlands of São Joaquim National Park, to contribute with the knowledge of its flora. Eight genera and 16 species of Myrtaceae were found: Acca sellowiana, Blepharocalyx salicifolius, Eugenia handroi, Myrceugenia (8 spp.): M. acutata, M. alpigena, M. euosma, M. miersiana, M. myrcioides, M. oxysepala, M. pilotantha, and M. regnelliana, Myrcia (2 spp.): M. aethusa and M. hartwegiana, Myrrhinium atropurpureum, Psidium salutare, and Siphoneugena reitzii. Descriptions, illustrations, an identification key and commentaries are presented. Other studies about Myrtaceae in highland areas of Southern Brazil present Myrceugenia as the richest genus in species, while other mentioned genera were not registered in SJNP upper highlands. The family's richness patterns and diversity in a local and regional scale should be better investigated in the Atlantic Forest.
\end{abstract}

Key words: floristic composition, mixed forest, Myrceugenia, taxonomy, Urubici.

\section{Resumo}

Trabalhos sobre a composição florística da Mata Atlântica mostram que Myrtaceae é uma das famílias mais ricas em número de espécies arbóreas. No Sul do Brasil Myrtaceae está presente principalmente em formações florestais, como as florestas pluviais latifoliadas, florestas nebulares latifoliadas, florestas mistas lati-aciculifoliadas (mata com Araucaria) e as florestas estacionais semideciduais. O objetivo desse estudo foi realizar o tratamento florístico das espécies de Myrtaceae encontradas nas áreas altomontanas do Parque Nacional de São Joaquim, para contribuir com o conhecimento de sua flora. Foram registrados oito gêneros e 16 espécies de Myrtaceae: Acca sellowiana, Blepharocalyx salicifolius, Eugenia handroi, Myrceugenia (8 spp.): M. acutata, M. alpigena, M. euosma, M. miersiana, M. myrcioides, M. oxysepala, M. pilotantha e $M$. regnelliana, Myrcia (2 spp.): M. aethusa e M. hartwegiana, Myrrhinium atropurpureum, Psidium salutare e Siphoneugena reitzii. São apresentadas descrições, ilustrações e uma chave de identificação e comentários. Outros estudos sobre Myrtaceae em áreas altomontanas da Região Sul do Brasil apresentaram Myrceugenia como o gênero mais rico em espécies, enquanto outros gêneros citados não foram registrados nas regiões altomontanas do PNSJ. Os padrões de riqueza e diversidade da família em escala local e regional devem ser melhor investigados na Mata Atlântica.

Palavras-chave: composição florística, floresta ombrófila mista, Myrceugenia, taxonomia, Urubici.

\footnotetext{
${ }^{1}$ Universidade Federal de Santa Catarina, Depto. Botânica, Prog. Pós-graduação em Biologia de Fungos Algas e Plantas, Campus Universitário Prof. João Davi Ferreira Lima, R. Eng. Agronômico Andrei Christian Ferreira s/n, Trindade, 88040-900, Florianópolis, SC, Brazil.

${ }^{2}$ Universidade Federal de Santa Catarina, Depto. Botânica, Centro de Ciências Biológicas, Campus Universitário Prof. João Davi Ferreira Lima, R. Eng. Agronômico Andrei Christian Ferreira s/n, Trindade, 88040-900, Florianópolis, SC, Brazil.

3 ORCID: < https://orcid.org/0000-0002-5457-6369>

${ }^{4}$ Author for correspondence: wagner.mariana@gmail.com
} 


\section{Introduction}

Myrtaceae encompasses 142 genera and 6,009 species (Wilson 2011; WCSP 2018). The distribution of Myrtaceae is pantropical, with extensions to subtropical and temperate zones, but the family occurs predominantly on the Southern Hemisphere, in the continents that once formed Gondwana (Thornhill et al. 2015). Important characteristics of Myrtaceae are flaky bark, simple trichomes with one or two cells, leaves with entire margins and sparse pellucid glands, half inferior to inferior ovaries, usually numerous stamens, internal phloem, vestured pits on the xylem vessels and the presence of terpenes as secondary metabolites (Wilson et al. 2001).

According to Wilson et al. (2005) Myrtaceae is constituted by two subfamilies, Psiloxyloideae (with two genera, Psiloxylon Thouars ex Tul. and Heteropyxis Harv.)S and Myrtoideae (all remaining genera), with 15 tribes. All the American species in the family belong to tribe Myrteae, excepting the Chilean Metrosideros stipularis (Hook. \& Arn.) Hook. f. from Metrosidereae (McVaugh 1968; Lucas et al. 2005; Vasconcelos et al. 2017). Myrteae is comprised of exclusively fleshy fruited Myrtaceae, with 51 genera and ca. 2,500 species (Lucas et al. 2007; Vasconcelos et al. 2017). Based on embryo characteristics described by Candolle (1827), Berg subdivided the American Myrteae in three subtribes, Myrtinae O.Berg, Myrciinae O.Berg, and Eugeniinae O.Berg (Berg 1855, 1856, 1857, $1858,1859)$ which were widely accepted until phylogenetic analyses based on molecular data have shown that they are polyphyletic (Lucas et al. 2007; Vasconcelos et al. 2017).

In Brazil Myrtaceae is represented by 23 genera and 1,026 species (BFG 2018). In many studies that address the floristic composition of the Atlantic forest, Myrtaceae appears as the richest or one of the richest families in number of tree species (e.g., Falkenberg \& Voltolini 1995; Koehler et al. 2002; Falkenberg 2003; Martini et al. 2007; Pereira-Silva et al. 2007; Meireles et al. 2008; Martins-Ramos et al. 2011; Higuchi et al. 2012).

In the article by the Brazil Flora Group (BFG 2018) about seed plant diversity in Brazil, Myrtaceae appears as the sixth richest plant family in the Atlantic Forest. In the Forest and Floristic Inventory of Santa Catarina, Myrtaceae appears as the second richest family in the
Araucaria forest, after Asteraceae (Gasper et al. 2013). Not only in Santa Catarina, but throughout the world's tropical and subtropical highland forests are among the most threatened ecosystems (Myers 1988; Hamilton et al. 1995; Rezende et al. 2015).

The upper highlands of São Joaquim National Park (SJNP) are important areas of conservation of subtropical highland forests. In an early inventory of the Myrtaceae from the municipality of São Joaquim, with a mean elevation of 1,360 m, Mattos (1957) recorded 24 species. However, in their Myrtaceae contributions for the Flora Ilustrada Catarinense (FIC), Legrand \& Klein (1967, 1969a,b, 1970, 1971a,b, 1972, 1977, 1978) analyzed specimens from areas throughout the state of Santa Catarina, but the upper highlands of São Joaquim National Park (SJNP) were not among their sampled areas.

The objective of this study was to survey the Myrtaceae from upper highland areas (above $1,000 \mathrm{~m}$ ) of São Joaquim National Park (SJNP) and to present updated descriptions, illustrations, an identification key to species, and taxonomic and ecological comments for each species.

\section{Material and Methods}

Study area

São Joaquim National Park $\left(28^{\circ} 03^{\prime}-18^{\prime}\right.$ 'S, $49^{\circ} 20^{\prime}-39^{\prime} \mathrm{W}$ ) comprises about 49,300 ha in the municipalities of Urubici, Bom Jardim da Serra, Orleans and Grão Pará, in Santa Catarina, Brazil (Fig. 1). It was created in 1961 to preserve the highly exploited Araucaria forests, which suffered from timber exploitation (Alarcon \& Silva 2007). Vegetation types in São Joaquim National Park (hereafter SJNP) include broadleaf rain forests, broadleaf cloud forests, mixed needle and broadleaf forests (Araucaria forests) and highland grasslands. The terrain is formed by basalt and sandstone formations (Ministério do Meio Ambiente 2017), acts as a loading and unloading area of the aquifer Guarani, and it is home to headwaters of important rivers, such as Canoas, Pelotas and Tubarão. The average yearly temperature is $12{ }^{\circ} \mathrm{C}$ (Ministério do Meio Ambiente 2017). According to the Köppen-Geiger classification, the climate in the region of SJNP is Cfa subtropical humid, oceanic without a dry season, with hot summers (Peel et al. 2007). The minimum elevation is $300 \mathrm{~m}$ and the maximum is $1,826 \mathrm{~m}$ (Ministério do Meio Ambiente 2017). 


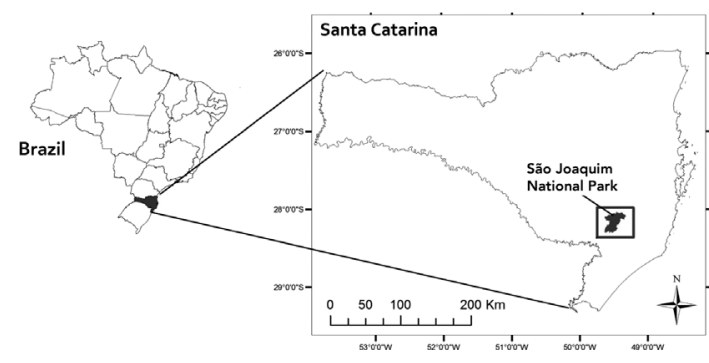

Figure 1 - Map indicating the location of São Joaquim National Park in Santa Catarina, Brazil. Modified from Figure 1 from Vianna et al. (2015), with permission from Geografia, Rio Claro.

\section{Methods}

Five expeditions for collecting specimens at SJNP were undertaken between July 2014 and February 2015. The specimens were deposited in the Herbarium FLOR. In addition to specimens collected for the present study, materials from FURB, HAS, HBR, ICN, MBM, PACA, RB, SPF, and UPCB (acronyms according to Thiers, continuously updated) were also analyzed.

Species descriptions were based on specimens collected in the area of study, and when these were insufficient due to a lack of reproductive structures, specimens from other areas were analyzed and included as additional material. The morphological terminology followed Radford et al. (1976) and specific taxonomic studies for the family (Landrum 1981, 1986; Landrum \& Kawasaki 1997). Generic descriptions were based on the literature (Landrum 1981, 1986; Proença 1990; Landrum \& Kawasaki 1997; Nic Lughadha 1997; Faria 2010) and on collected specimens. Names of species and genera followed Myrtaceae in BFG (2018).

Pedicels were measured from the point of insertion in the branch or inflorescence peduncle and the base of the hypanthium. Length of the inflorescence peduncle was measured from the point of insertion in the branch to the first inflorescence branch. The hypanthium was measured from its base to top of the ovary. Leaf color descriptions are based on dry specimens. The system of Terrestrial Ecoregions of the World by Olson et al. (2001) and the phytophysiognomy classification by Oliveira-Filho (2009) were used to describe the study site.

\section{Results and Discussion}

The taxonomic study of Myrtaceae from the upper highlands of SJNP, including areas from $1,000 \mathrm{~m}$ to $1,826 \mathrm{~m}$ elevation, revealed eight genera and 16 species: Myrceugenia O.Berg $(8$ spp.), Myrcia DC. (2 spp.), Acca O.Berg (1 sp.), Blepharocalyx O.Berg (1 sp.), Eugenia L. (1 sp.), Myrrhinium Schott (1 sp.), Psidium L. (1 sp.), and Siphoneugena O.Berg (1 sp.) (Figs. 2-6).

\section{Identification key to the species of Myrtaceae from São Joaquim National Park}

1. Leaf blades narrowly elliptic; calyx closed in bud; hypanthium prolonged above ovary, forming a tubular structure with the calyx, and deciduous after anthesis, leaving a circular scar on the fruit

\subsection{Siphoneugena reitzii}

1'. Leaf blades elliptic, obovate, ovate, lanceolate, oblanceolate or obtrullate; if narrowly elliptic, then other leaf shapes are also present; calyx open in bud; hypanthium not prolonged above ovary, exceeded by

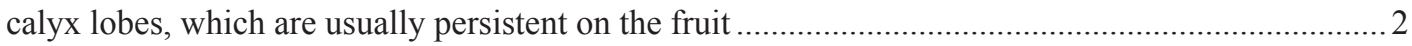

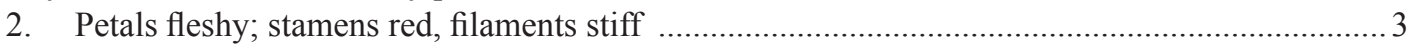

2'. Petals membranous; stamens white, filaments flexible ............................................................... 4

3. Leaf blades ovate or obovate, adaxially sparsely pubescent to lanuginose, abaxially lanuginose; flowers solitary; petals $21-22 \times 18-21 \mathrm{~mm}$; stamens 60-90 1.1. Acca sellowiana

3'. Leaf blades narrowly elliptic, glabrous on both surfaces; flowers arranged in dichasia; petals ca. $5.1 \times 4.1 \mathrm{~mm}$; stamens $4-8$. 6.1. Myrrhinium atropurpureum

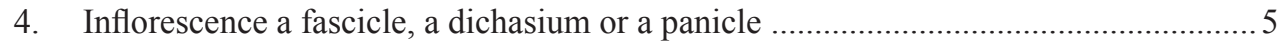

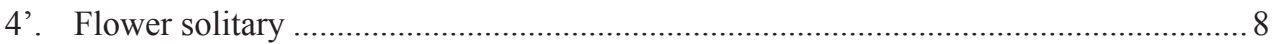

5. Young branches cylindrical; leaf blades ovate or elliptic, base cuneate, apex acute to obtuse; inflorescence a fascicle; berries $10-23 \mathrm{~mm}$ diam. 
5'. Young branches flattened; leaf blades lanceolate, narrowly elliptic, obovate, elliptic, base attenuate to cuneate, apex obtuse, rounded, acuminate or caudate; inflorescence a dichasium or panicle; berries 4-8 mm diam.

6. Young branches glabrous; leaf blades lanceolate; ovary with ca. 10 ovules per locule

2.1. Blepharocalyx salicifolius

6'. Young branches pubescent to densely pubescent; leaf blades lanceolate, narrowly elliptic, elliptic, or obovate; ovary with $2-3$ ovules per locule

7. Leaf blades lanceolate or narrowly elliptic; inflorescence a dichasium or panicle; bracteoles lanceolate; thecal arrangement with pollen sacs at the same level; ovary 3-locular...

5.1. Myrcia aethusa

7'. Leaf blades obovate or elliptic; inflorescence a panicle; bracteoles trullate; thecal arrangement with pollen sacs at different levels; ovary 2-locular 5.2. Myrcia hartwegiana

8. Subshrubs with main shoot underground, 20-40 cm long; trichomes simple; young branches grooved; leaf blades light-green on both sides; secondary veins prominent adaxially; flower pedicel $>15 \mathrm{~mm}$; stigma peltate 7.1. Psidium salutare

8'. Shrubs and trees, 1-10 m high; trichomes simple and dibrachiate; young branches smooth; leaf blades discolor; secondary veins impressed or indistinct adaxially; flower pedicel $\leq$ $15 \mathrm{~mm}$; stigma punctiform

9. Leaf blades mostly obovate, rarely elliptic, adaxially glabrous; pedicel 1-2 mm long; calyx lobes and bracteoles resembling each other, bracteoles lanceolate, 4-7 $\mathrm{mm}$ long, calyx lobes lanceolate or triangular, ca. $4 \mathrm{~mm}$ long

4.6. Myrceugenia oxysepala

9'. Leaf blades elliptic, narrowly elliptic, oblanceolate, rarely obovate, adaxially with very few scattered trichomes to pubescent throughout the blade or sparsely pubescent along the midrib; pedicel 2-15 $\mathrm{mm}$ long; calyx lobes and bracteoles not resembling each other, bracteoles lanceolate, narrowly triangular, triangular, deltate, ovate or very widely ovate, $0.9-5 \mathrm{~mm}$ long, calyx lobes triangular, deltate, shallowly deltate, ovate, widely ovate or very widely ovate, $1.4-6 \mathrm{~mm}$ long ..... 10

10. Leaf blades mostly obtrullate, sometimes obovate or oblanceolate; bracteoles deltate or very widely ovate 4.2. Myrceugenia alpigena

10'. Leaf blades elliptic, narrowly elliptic, obovate, never obtrullate; bracteoles ovate, triangular, narrowly triangular or lanceolate .11

11. Calyx lobes exceeding the globe of petals in bud, calyx lobes usually 1.2-2 times as long as wide.

11'. Calyx lobes shorter than the globe of petals in bud, calyx lobes usually

$0.8-1$ time as long as wide

12. Leaf blades with apex acuminate to acute; trichomes only dibrachiate

12'. Leaf blades with apex acute to obtuse, never acuminate; trichomes simple and dibrachiate.

13. Petioles $1.1-2 \mathrm{~mm}$ long; leaf blades $13-20 \times 4-6 \mathrm{~mm}$, narrowly elliptic; one flower per leaf axil; buds ca. $4 \times 2-3 \mathrm{~mm}$; bracteoles ovate, ca. $2 \times 1-1.5 \mathrm{~mm}$; ovary 2-locular

4.3. Myrceugenia euosma

13'. Petioles 3-6 mm long; leaf blades 35-110 × 15-36 mm, obovate or elliptic; $1-3$ flowers per leaf axil; buds 5-9 $\times 3-9$ $\mathrm{mm}$; bracteoles lanceolate, narrowly triangular or triangular, $2.2-5 \times 0.7-3 \mathrm{~mm}$; ovary 3-4 locular 4.5 Myrceugenia myrcioides

14. Trichomes yellowish to golden-brown, nearly all simple, erect; leaf blade with erect trichomes abaxially, secondary and intramarginal veins prominent abaxially 
14'. Trichomes reddish-brown, simple and dibrachiate, appressed; leaf blades with trichomes usually appressed abaxially, secondary and intramarginal veins impressed abaxially.

4.7. Myrceugenia pilotantha

15. Young branches distinctly flattened; leaf blades $26-46 \times 1-16 \mathrm{~mm}$; pedicel glabrous, $11-23 \mathrm{~mm}$ long; bracteoles glabrous; calyx lobes $1.4-1.7 \mathrm{~mm}$ long..... 4.1. Myrcengenia acutata

$15^{\prime}$. Young branches cylindrical; leaf blades $7-23 \times 2-12 \mathrm{~mm}$; pedicel sparsely pubescent to pubescent, 2-13 mm long; bracteoles pubescent; calyx lobes 1.2-1.4 $\mathrm{mm}$ long

4.8 Myrceugenia regnelliana

\section{Taxonomic treatment}

\section{Acca O. Berg.}

Acca comprises three species, with two of them occurring in the Peruvian Andes, and one in Brazil, Acca sellowiana (Landrum 1986).

1.1. Acca sellowiana (O.Berg) Burret, Repert. Spec. Nov. Regni Veg. 50: 59 (1941). $\quad$ Figs. 2a; 5a

Shrubs or trees, 1.9-4 m high. Young branches flattened, sparsely pubescent to lanuginose. Trichomes white, curled or straight, appressed or erect. Petioles $4.3-6.4 \times 0.9-1.5 \mathrm{~mm}$, canaliculate adaxially, pubescent on both surfaces; leaf blades 31-47 × 16-28 mm, ovate or obovate, chartaceous to subcoriaceous, dark green to dark brownishgreen adaxially, lighter green or brownish-green abaxially, pubescent along the midrib, sparsely pubescent throughout the blade, lanuginose when young adaxially, lanuginose abaxially; base cuneate, apex obtuse or rounded; midrib canaliculate adaxially, prominent abaxially, secondary veins 5-8 pairs, impressed adaxially, slightly prominent abaxially, intramarginal vein $1.4-1.9 \mathrm{~mm}$ from the margin. Flowers solitary, pedicel 10-13 × 1.2-1.7 $\mathrm{mm}$, sparsely pubescent or lanuginose; buds $11.1-$ $14.6 \times 1-10 \mathrm{~mm}$; bracteoles 3-3.7 × 0.6-1.1 mm, lanceolate, persistent; calyx open in bud, imbricate, lobes $4,5.3-8.5 \times 5.6-7.7 \mathrm{~mm}$, very widely ovate or very widely obovate, concave, glabrous adaxially, lanuginose abaxially; petals 4 , reddish to pink adaxially, white abaxially, fleshy, 21-22 $\times$ 18-21 mm, very widely obovate, concave, glabrous adaxially, glabrous abaxially; hypanthium 9.2-10 $\times 4.5-4.8 \mathrm{~mm}$, lanuginose, cuneiform; stamens 60 to 90 , red, filaments stiff, $17.7-20.7 \times 0.7-0.9 \mathrm{~mm}$, anthers $1.5-1.6 \times 1.1-1.3 \mathrm{~mm}$, thecal arrangement oblique; stigma punctiform, ovary ca. $4.4 \times 2.8 \mathrm{~mm}$, 4-locular, ca. 22 ovules per locule. Berry widely ellipsoid to spheroid, 48-55 × 40-49 mm, green, glabrous, calyx persistent; seeds numerous, ca. 3 $\times 3 \mathrm{~mm}$. Embrio myrtoid, c-shaped with hypocotyl and cotyledons equal in shape.
According to Landrum (1986), A. sellowiana occurs in grasslands and Araucaria forests of Southern Brazil in the states of Santa Catarina and Rio Grande do Sul, and also in the 'quebradas' (narrow mountain passes) in Uruguay. Myrtaceae in BFG (2018) reported the distribution of this species also in Rio de Janeiro, São Paulo and Paraná states. However, the records of $A$. sellowiana in São Paulo and Rio de Janeiro are sporadic, and most likely of cultivated specimens collected on farms. This species occurs in the Atlantic forest and the Pampa grasslands (Myrtaceae in BFG 2018). In the upper highlands of SJNP A. sellowiana is abundant in the Araucaria Forest in Campos de Santa Bárbara in Urubici at an elevation of ca. 1,400 m. The species occurs mostly along river margins or bordering Araucaria forest.

The flowers are present between October and December and fruits appear from February to May. Specimens analysed: Urubici, salto do Rio Vacariano, 9.X.2001, G. Hatschbach et al. 72530 (MBM); subida para Campo dos Padres, 15.V.2004, fr., J.M. Silva \& L.R. Lima 4057 (MBM); salto do Rio Avencal, base, 16.X.2004, fl., G. Hatschbach et al. 78101 (MBM); Cachoeira do Avencal, 15.XII.2008, fl., J.M. Silva et al. 7151 (MBM). Santa Terezinha, 1,055 m, 2800'47's, 49²9’31'W, fr., 7.IV.2009, M. Verdi et al. 1911 (FURB); Campos de Santa Bárbara, 1,368 m, 2808'31'"S, 49 38'08”'W, 24.XI.2014, fl. and fl., M.A. Wagner et al. 144 (FLOR); trilha cachoeira (estrada), 1,403 m, $28^{\circ} 08^{\prime} 42^{\prime \prime S}, 49^{\circ} 3709^{\prime \prime} \mathrm{W}, 9 . I I .2015$, fr., M.A. Wagner et al. 170 (FLOR).

\section{Blepharocalyx O. Berg.}

Blepharocalyx occurs from the Caribbean Islands throughout South America to Chile. There are three species of Blepharocalyx in Brazil: Blepharocalyx eggersii (Kiaersk.) Landrum, from Amazonas, Blepharocalyx myriophyllus (Casar.) Morais \& Sobral, from the Serra do Caraça in Minas Gerais, and Blepharocalyx salicifolius (Kunth) O.Berg widespread in extra-Amazonian Brazil (Landrum \& Kawasaki 1997; Myrtaceae in BFG 2018). 


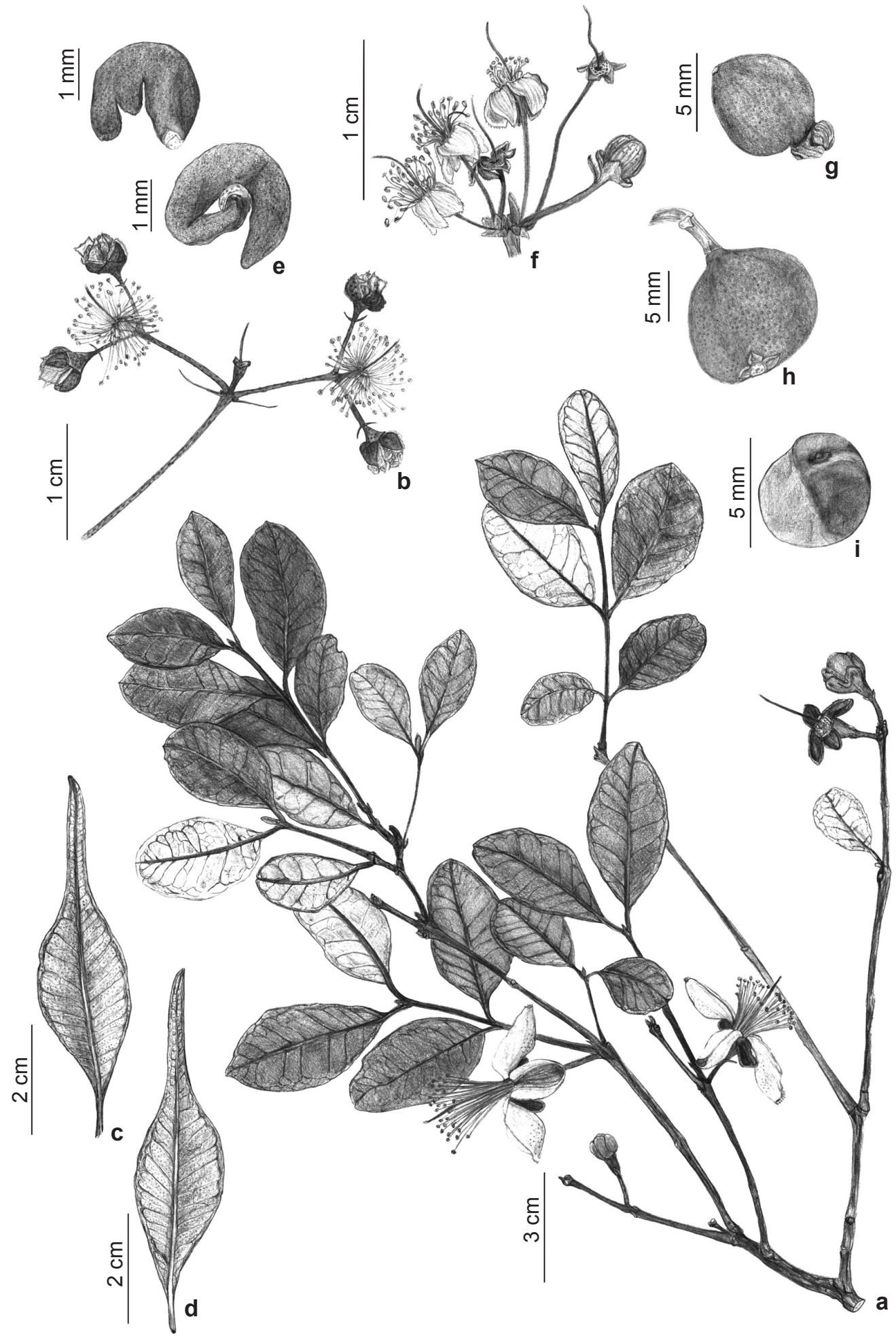

Figure 2 - a. Acca sellowiana - branch with flower buds, flowers and older flower without petals. b-e. Blepharocalyx salicifolius - b. inflorescence with flower buds, flowers and flower without petals; c. leaf adaxially; d. leaf abaxially; e. myrtoid embryos. f-i. Eugenia handroi - f. inflorescence with flower buds, flowers and flower without petals; g. young fruit; h. mature fruit i. eugenioid embryo. (a. M.A. Wagner 144; b-d. P. Fiaschi 4445; e. O. Bueno 4296; f. R.M. Klein 7597; g. R.M. Klein 8682; h. R. Reitz 8380; i. R.M. Klein 8682). 
2.1. Blepharocalyx salicifolius (Kunth) O.Berg, Linnaea 27: 413 (1856). Figs. 2b-e; 5b-c

Trees, 8-16 $\mathrm{m}$ high. Young branches flattened, glabrous. Petioles 3-7.7 × 0.4-0.7 mm, canaliculate adaxially, glabrous on both surfaces; leaf blades $40-58 \times 12-18 \mathrm{~mm}$, lanceolate, chartaceous, bright green on both surfaces, glabrous to sparsely pubescent and ciliolate when young adaxially, glabrous to sparsely pubescent along midrib abaxially, with very small pellucid glands visible throughout; base attenuate, apex acuminate or caudate; midrib impressed with proximal portion slightly canaliculate adaxially, prominent abaxially, secondary veins ca. 25 pairs, impressed on both surfaces, intramarginal vein $0.2-0.4 \mathrm{~mm}$ from the margin. Inflorescence a single dichasium or panicle, ca. 7 flowers, peduncle 13-15 × 0.5-0.6 mm, glabrous, secondary branches of dichasium 4-10 mm long; buds $2.8-3.3 \times 1.7-2.6 \mathrm{~mm}$; bracteoles 3.9-5 $\times$ 0.4-0.6 mm, narrowly triangular or lanceolate, caducous; calyx open in bud, imbricate, lobes $4,2.4-2.6 \times 1.4-1.8 \mathrm{~mm}$, ovate, strongly concave, ciliate and pubescent adaxially, sparsely pubescent to glabrous abaxially; petals 4, white, membranous, ca. $2.4 \times 1.7 \mathrm{~mm}$, obovate, ciliate, pubescent on both surfaces, white; hypanthium 2.1-2.5 × 2-2.4 mm, glabrous, cotyliform; stamens 80-160, white, filaments flexible, 1.9-4.6 $\times 0.1-0.2 \mathrm{~mm}$, anthers $0.3-0.5 \times 0.4 \mathrm{~mm}$, thecal arrangement parallel; stigma punctiform, ovary ca. $0.7 \times 0.8 \mathrm{~mm}, 2$-locular ca. 10 ovules per locule. Berry spheroid, 4-5.4 x 4-5.4 mm, glabrous, calyx caducous leaving a square scar; seeds $1-4$, 2.9-3.6 $\times 2.1-2.9 \mathrm{~mm}$. Embryo myrtoid, c-shaped, hypocotyl swollen, cotyledons very small.

According to Landrum (1986), Blepharocalyx salicifolius occurs in Brazil (from the states of Goiás to Rio Grande do Sul), Paraguay, Uruguay, Argentina, Bolivia and Ecuador. Blepharocalyx. salicifolius also occurs in Bahia, Distrito Federal, Mato Grosso do Sul, and Mato Grosso states in the Caatinga scrubland, Cerrado woodlands, Atlantic forest and Pampa grasslands (Myrtaceae in BFG 2018). In the state of Santa Catarina it occurs in riparian forests, in Araucaria forests on moist soil, and in terrain depressions, and it requires medium to high exposure to light (Legrand \& Klein 1978). In the upper highlands of SJNP it occurs in riparian Araucaria forests in the Campos de Santa Bárbara and other areas of the Park, at elevations of $1,000-1,350 \mathrm{~m}$.
Blepharocalyx salicifolius is rare in SJNP. It flowers in December and the fruits appear from February to April.

Specimens analysed: Urubici, Corvo Branco, 1,000 m, 17.II.1995, G. Hatschbach et al. 61720 (MBM); Caverna dos Bugres, 1,000 m, 8.XII.2000, fl., G. Hatschbach et al. 71695 (MBM); Rod. Urubici-Urupema, 9.II.2007, O.S. Ribas \& G. Hatschbach 7534 (MBM); Campos de Santa Bárbara, estrada do alojamento para a cachoeira, 1,351 m, 2808'26”'S, 49³7’36”'W, 25.XI.2014, fl., M.A. Wagner et al. 145 (FLOR); 11.XII.2014, P. Fiaschi et al. 4445 (FLOR).

Additional material: BRAZIL. SANTA CATARINA: Campos Novos, a mais ou menos $10 \mathrm{~km}$ de Vargem e a 14 km de Abdon Batista, 12.II.1981, fr., S. Sohn \& J.M. Campos 30 (FLOR).

\section{Eugenia L.}

Eugenia L. occurs from Mexico and the Caribbean Islands throughout South America to northern Argentina (Landrum \& Kawasaki 1997). There are approximately 379 species of Eugenia in Brazil (Myrtaceae in BFG 2018).

3.1. Eugenia handroi (Mattos) Mattos, Loefgrenia; 105: 2 (1995).

Figs. 2f-i; $5 \mathrm{~d}$

Treelet, ca. $2.5 \mathrm{~m}$ high. Young branches cylindrical, sparsely pubescent. Trichomes white or yellow, simple, curled or straight, very small, erect or long appressed. Petioles $3.5-4 \times 0.5-0.8 \mathrm{~mm}$, pubescent, canaliculate adaxially, very sparsely pubescent to glabrous abaxially; leaf blades 21-32 $\times 13-16 \mathrm{~mm}$, ovate to elliptic, chartaceous to subcoriaceous, dark brown adaxially, lighter brown abaxially, glabrous adaxially, pubescent proximally along the midrib abaxially; base cuneate, apex acute to obtuse; midrib impressed and slightly canaliculate proximally adaxially, prominent abaxially, secondary veins ca. 10 pairs, impressed adaxially, impressed to very slightly prominent abaxially, intramarginal vein $0.9-1 \mathrm{~mm}$ from the margin. Inflorescence a fascicle with 4 to 6 flowers; bracts ca. $2 \mathrm{~mm}$ long, oblong, ciliate, rachis ca. $1 \times 1 \mathrm{~mm}$; pedicel $2-10 \times 0.5 \mathrm{~mm}$, pubescent; buds ca. $3.1 \times 3.4 \mathrm{~mm}$; bracteoles $1.1 \times 0.9 \mathrm{~mm}$, deltate, pubescent, ciliate, concave adaxially, slightly keeled abaxially, caducous; calyx open in bud, imbricate, lobes 4 or 5, 1-1.1 × 1.2-1.8 mm, deltate to shallowly triangular, ciliate, glabrous, concave adaxially, pubescent abaxially; petals 4 or 5, white, membranous, ca. $3.7 \times 3.7 \mathrm{~mm}$, circular, ciliate, glabrous, concave adaxially, slightly pubescent abaxially; hypanthium ca. $1.1 \times 0.9 \mathrm{~mm}$, pubescent to lanate, obdeltoid; stamens 34-107, 
white, filaments flexible, $3.3-4.3 \times 0.1-0.2 \mathrm{~mm}$, anthers $0.5-0.6 \times 0.4-0.5 \mathrm{~mm}$, thecal arrangement parallel; stigma punctiform, ovary ca. $1 \times 0.5 \mathrm{~mm}$, ovary 2 locular, ca. 2 ovules per locule. Berry spheroid, 10-23 × 10-23 mm, orange to red when mature, glabrescent, calyx persistent or caducous, leaving a circular scar; seed one, ca. $5.7 \mathrm{~mm}$ diam. Embryo eugenioid, cotyledons solid, ellipsoid, hypocotyl short.

Eugenia handroi occurs in the Atlantic Forest from Espírito Santo to Rio Grande do Sul (Myrtaceae in BFG 2018). It occurs in high altitudes of Mantiqueira Range, Serra do Mar Range and in the eastern border of the Southern Plateau, preferentially on soils with high humidity and indirect exposure to light, occurring inside or along the margin of Araucaria forests (Legrand \& Klein 1977).

There are records of two species of Eugenia near the borders of SJNP. One of these species is Eugenia handroi, with records in Urubici at about 1,600 $\mathrm{m}$ and at Campo dos Padres, a nearby area similar to Morro da Igreja in SJNP. Eugenia handroi was included, even though it is not abundant in the area and has not yet been collected within the park. There is also one record of Eugenia uniflora L. (Hatschbach 78124, MBM) from Cachoeira do Avencal, an area near the limits of SJNP. As there is only one record of this species outside SJNP and it is a species commonly propagated by people for its fruits and as ornamental, we decided not to include it in the current work.

Eugenia handroi flowers around October and the fruits appear in February. It occurs at elevations between 1,500 and 1,600 m.

Specimens analysed: Urubici, próximo à fábrica de pasta mecânica, 1,600 m, 22.X.1981, fl., J. Mattos 22773 (MBM); Campo dos Padres, estrada pelo vale do Rio dos Bugres, próximo à propr. do Sr. Abel Luiz Fabre, 1,522 m, 27057'06.9'"S, 49 24'58'W, 14.II.2012, fr., N.F.O. Mota et al. 2528 (RB).

4. Myrceugenia O.Berg, Linnaea 27: 131 (1856).

Shrubs or trees. Trichomes simple and dibrachiate, mostly dibrachiate. Flowers usually solitary, less often a dichasium or a bracteate shoot, the pedicels usually superimposed on a row in the axil of leaves or bracts; bracteoles usually persistent until the fruit matures; calyx usually open in bud or, in two species, closed and falling as a calyptra; lobes 4; petals 4, white, membranous; stamens ca. 40 to over 500 , flexible, white; hypanthium broadly cuneiform to depressed obovoid, not prolonged above the ovary, ovary $2-4$-locular, $2-20$ ovules per locule. Berry ellipsoid to spheroid; crowned by the calyx lobes or caducous leaving a circular scar; seeds 1-5; embryo myrcioid, cotyledons thin, leafy, folded into a bundle, hypocotyl cylindrical, narrow, as long as the cotyledons.

Myrceugenia occurs from tropical highland areas in Brazil to subtropical Brazil and in Chile and Argentina (Landrum \& Kawasaki 1997; Murillo-A et al. 2016). Approximately 32 species of Myrceugenia occur in Brazil, most of which (ca. $24 \mathrm{spp}$.) are recorded in the state of Santa Catarina (Myrtaceae in BFG 2018).

4.1. Myrceugenia acutata D.Legrand, Darwiniana 11: 351 (1957).

Figs. 3a-c; 5e-g

Shrubs, treelets or trees, 1.6-4 m high. Young branches distinctly flattened, sparsely pubescent. Trichomes reddish-brown, dibrachiate and simple, appressed. Petioles 3-4.1 $\times 0.7-0.8 \mathrm{~mm}$, canaliculate adaxially, pubescent on both surfaces; leaf blades 26-46 $\times 10-16 \mathrm{~mm}$, narrowly elliptic to elliptic, coriaceous, dark green or brownish-green adaxially, lighter green or brownish-green abaxially, glabrous to very sparsely pubescent along midrib adaxially, glabrous to very sparsely pubescent abaxially; base attenuate to cuneate, apex acuminate to acute; midrib canaliculate proximally and slightly impressed distally adaxially, prominent abaxially, secondary veins 5-12 pairs, inconspicuous adaxially, impressed abaxially, intramarginal vein usually inconspicuous, when visible $0.2-0.3 \mathrm{~mm}$ from the margin. Flowers solitary, pedicel 11-23 $\times 0.4-0.5 \mathrm{~mm}$, glabrous; buds $2.8-4.3 \times 1.6-1.9$ $\mathrm{mm}$; bracteoles $0.9-1.4 \times 0.7-0.8 \mathrm{~mm}$, ovate to triangular, glabrous, persistent; calyx open in bud, smaller than the globe of petals, valvate, lobes $1.4-1.7 \times 1.5-1.6 \mathrm{~mm}$, usually $0.8-1$ time as long as wide, deltate to shallowly deltate, very sparsely pubescent adaxially, puberulent abaxially; petals ca. $2.9 \times 2.5 \mathrm{~mm}$, widely obovate, strongly concave, glabrous on both surfaces; hypanthium 1.4-1.6 $\times$ $1.2-1.3 \mathrm{~mm}$, densely pubescent, obconic; stamens filaments $2.6-4.2 \times 0.1-0.2 \mathrm{~mm}$, anthers $0.3-0.4$ $\times 0.3-0.4 \mathrm{~mm}$; stigma punctiform, ovary ca. $0.6 \times$ $0.7 \mathrm{~mm}, 2-$ locular, 3-6 ovules per locule. Berry ellipsoid to broadly ellipsoid, 7-7.7 $\times 4.5-5.2$ $\mathrm{mm}$, purple-black, sparsely puberulent, calyx persistent; seeds $1-2$, ca. $3.8 \times 3 \mathrm{~mm}$.

Myrcengenia acutata is distributed through Southern Brazil and in the states of São Paulo and Rio de Janeiro, in the Atlantic forest (Myrtaceae in BFG 2018). This species occurs in humid and shady environments (Legrand \& Klein 1970). In 


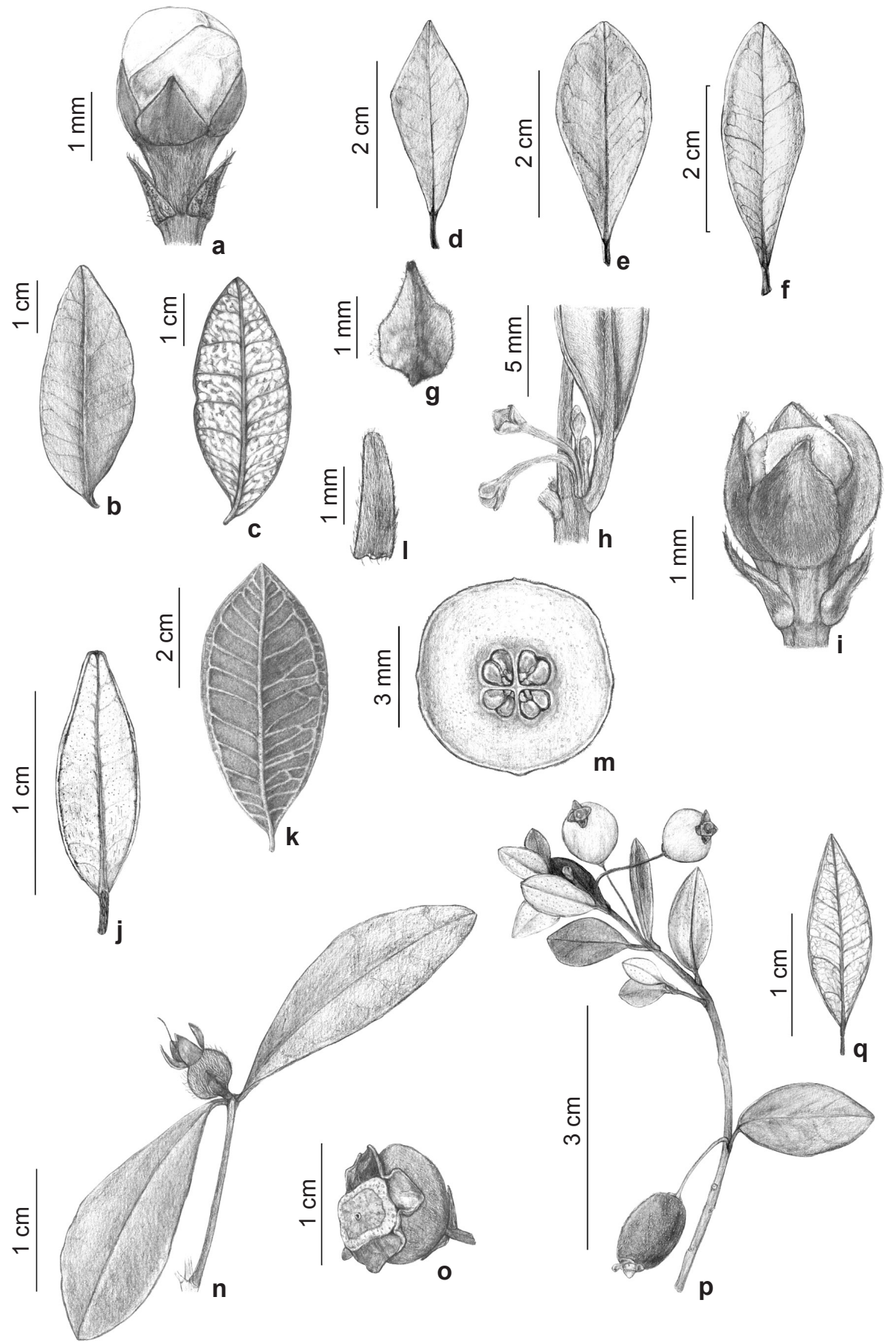

Figure 3 - a-c. Myrcengenia acutata - a. flower bud; b. leaf, adaxial surface; c. leaf, abaxial surface. d-h. Myrcengenia alpigena - d-f. leaf morphological variability, adaxial surface; g. bracteole; h. flower buds disposed on a row in leaf axil. i. Myrceugenia euosma - flower bud. k. Myrcengenia miersiana - leaf, abaxial surface. 1-m Myrceugenia myrcioides -1 . bracteole; $m$. transversal section of ovary. $n$. Myrcengenia oxysepala - branch with leaves and fruit. o. Myrceugenia pilotantha - fruit. j, p-q. Myrceugenia regnelliana - j. leaf, abaxial surface; $\mathrm{p}$. branch with leaves and fruit; q. leaf, abaxial surface. (a-c. M.A. Wagner 127; d-g. M.A. Wagner 113; h. M.A. Wagner 149; i. M.A. Wagner 141; j. M.A. Wagner 186; k. R. Reitz 12856; 1. M.A. Wagner 96; m. P. Fiaschi 4189; n. M.A. Wagner 172; o. M.A. Wagner 115; p-q. M.A. Wagner 137). 
the upper highlands of SJNP, M. acutata occurs in riparian Araucaria forests and cloud forests from 1,400 to $1,700 \mathrm{~m}$ elevation. The species flowers and bears fruit from September through December.

In SJNP M. acutata and M. regnelliana, are very similar morphologically and differ mostly in leaf features (see the identification key steps 15 and 15 ' for characters that differ between them). Myrceugenia acutata flowers and bears fruit between October and November in SJNP.

Specimens analysed: Bom Jardim da Serra, $14 \mathrm{~km}$ ao leste de Bom Jardim da Serra, boca da serra, 1,400 m, 24.XII.1982, A. Krapovickas \& Schinini 38288 (HAS); Morro da Igreja, 22.I.1960, J. Mattos 7488 (HAS); 1,700 m, 04.XII.1992, fl. and fr., D.B. Falkenberg \& F.A. Silva Filho 5866 (FLOR); Campos de Santa Bárbara, 1,371 m, 2808'S, 49³7' W, 21.IX.2014, fl. and fr., M.A. Wagner \& P. Fiaschi 126 (FLOR); 2808'30'S, 49'38'07' W, 30.X.2014, fl. and fr., M.A. Wagner et al. 127 (FLOR); Morro da Igreja, matinha nebular, antes do portão do Sindacta, $1,712 \mathrm{~m}$, 2807'08'S, 49²9'39'”, 26.XI.2014, M.A. Wagner et al. 159 (FLOR).

\subsection{Myrceugenia alpigena (DC.) Landrum,} Brittonia 32: 372 (1980). Figs. 3d-h; 5h-i

Shrubs and trees, 0.5 to $5 \mathrm{~m}$ high. Young branches flattened, pubescent to densely pubescent. Trichomes white, yellow or reddish-brown, simple and dibrachiate, appressed. Petioles 2-6.3 × 0.7-1 $\mathrm{mm}$, canaliculate adaxially, pubescent on both surfaces; leaf blades 20-57 × 9-22 mm, usually obtrullate, sometimes obovate, oblanceolate or narrowly elliptic, coriaceous, dark brownishgreen adaxially, lighter brownish-green to light brown abaxially, glabrous adaxially, pubescent to densely pubescent specially along the midrib abaxially; base attenuate, apex acute; midrib canaliculated proximally and slightly impressed distally adaxially, prominent abaxially, secondary veins 9-11 pairs, sometimes inconspicuous to impressed on both surfaces, intramarginal vein inconspicuous. Flowers solitary or $2(-4)$ on a row in the axil of leaves; pedicel $8-13 \times 0.6-0.8 \mathrm{~mm}$, pubescent; buds 2-3.7 × 1.5-3.6 mm; bracteoles $1.5-2.1 \times 1.2-2 \mathrm{~mm}$, deltate or very widely ovate, concave adaxially, keeled abaxially, persistent; calyx open in bud, imbricate, lobes 1.7-2.7 $\times$ 1.5-2.7 mm, very widely ovate to widely ovate, adaxially sparsely pubescent to pubescent towards the apex, concave, abaxially sparsely pubescent to pubescent; petals ca. $3 \times 3 \mathrm{~mm}$, very widely obovate, concave, glabrous adaxially, glabrous abaxially; hypanthium 1-2.1 × 1.5-2.6 mm, densely pubescent, depressed obovoid; stamens filaments $2.9-4.7 \times 0.1-0.2 \mathrm{~mm}$, anthers $0.5-0.7$ $\times 0.4-0.6 \mathrm{~mm}$; stigma punctiform, ovary $1.5-1.7$ $\times$ 1.5-2 mm, 3-4-locular, 3-9 ovules per locule. Berry obloid to spheroid, 2.9-5 × 3.5-6 mm, brown when imature, dark purple to black when mature, pubescent, calyx persistent; seeds 1-4, 3-4 × 2.5-4 mm.

Myrceugenia alpigena occurs in the state of Bahia and from the north of Minas Gerais to Rio Grande do Sul, in the Caatinga scrublands, the Cerrado woodlands and the Atlantic forest (Landrum 1981; Myrtaceae in BFG 2018). In the upper highlands of SJNP $M$. alpigena occurs at elevations of 1,400-1,730 $\mathrm{m}$ in cloud forests, mountainside and riparian Araucaria forests and on forest edges, near marshes and rocky outcrops.

In SJNP $M$. alpigena flowers between November and February. Immature green fruits were recorded in September and October, and mature fruits in November.

Specimens analysed: Bom Jardim da Serra, na Serra do rio do Rastro, 4.I.1960, J. Mattos 7099 (HAS); Desfiladeiro do Funil, II.1989, fl., M. Sobral et al. 6450 (MBM); Morro da Igreja, campestre do Malacara, 21.I.1960, J. Mattos 7266 (HAS); próximo ao alto, 1,700 m, 16.II.1995, fl., G. Hatschbach et al. 61650 (MBM); Campo dos Padres, 1,482 m, 27059'31.9' S, 49'24'43.9''W, 3.IV.2009, M. Verdi et al. 1938 (FURB). Xaxim, 1,407 m, 2804'57''S, 49³5'27.9''W, 27.IX.2009, M. Verdi \& A.L. Gasper 2073 (FURB); mata nebular na estrada da antena, $1,729 \mathrm{~m}, 28^{\circ} 07^{\prime} \mathrm{S}$, 49²9'W, 20.IX.2014, fr., M.A. Wagner \& P. Fiaschi 108 (FLOR); trilha do morro da igreja para o Rio Pelotas, 1,614 m, 280's, 49³0'W, 20.IX.2014, fr., M.A. Wagner \& P. Fiaschi 113 (FLOR); Campos de Santa Bárbara, trilha do italianinho, $1,382 \mathrm{~m}, 28^{\circ} 08^{\prime} \mathrm{S}$, 49³7'W, 21.IX.2014, M.A. Wagner \& Pedro Fiaschi 124 (FLOR); trilha da Pedra Furada, 2807'46''S, 49²8'18'W, 31.X.2014, fr., M.A. Wagner et al. 134 (FLOR); parcela PPBio módulo 1, TN065, 1,554 m, 2808'28'S, 49³6'54'”W, 25.XI.2014, M.A. Wagner et al. 150 (FLOR).

4.3. Myrceugenia euosma (O.Berg) D.Legrand, Anales Mus. Nac. Montevideo ser. 2, 4: 40 (1936).

Figs. 3i; 5j-1

Shrubs or trees 1.5 to $3.5 \mathrm{~m}$ high. Young branches flattened, densely pubescent. Trichomes reddish-brown or white, dibrachiate. Petioles 1.1-2 × 0.6-0.8 mm, canaliculate adaxially, pubescent on both surfaces; leaf blades 13-20 $\times$ 4-6 mm, narrowly elliptic, chartaceous, dark green adaxially, light brown abaxially, surface glabrous 
to sparsely puberulent along midrib adaxially, densely pubescent abaxially, punctuations very small black dots on abaxial surface; base attenuate, apex acuminate to acute; midrib entirely canaliculate to only canaliculate proximally adaxially, prominent abaxially, secondary veins 7-13 pairs, inconspicuous adaxially, inconspicuous to impressed abaxially, intramarginal vein $0.3-0.5$ $\mathrm{mm}$ from the margin. Flowers solitary, flower pedicel $5-13 \times 0.4-0.8 \mathrm{~mm}$; buds ca. $4 \times 2-3$ $\mathrm{mm}$; bracteoles ca. $2 \times 1-1.5 \mathrm{~mm}$, ovate, keeled, persistent; calyx open with lobes longer than the globe of petals in the bud, valvate, lobes ca. $3 \times 2$ $\mathrm{mm}$, usually 1.5 times as long as wide, triangular, concave, sparsely pubescent adaxially, pubescent abaxially; petals ca. $2.5 \times 3.5 \mathrm{~mm}$, depressed obovate, concave and glabrous adaxially, glabrous abaxially; hypanthium ca. $2 \times 2 \mathrm{~mm}$, densely pubescent, obdeltoid; stamens filament 2.4-3.7 $\times$ $0.1-0.2 \mathrm{~mm}$, anthers $0.4-0.5 \times 0.4-0.5 \mathrm{~mm}$; stigma punctiform, ovary ca. $1.4 \times 1.5 \mathrm{~mm}$, 2-locular, with 5 to 6 ovules per locule. Berry broadely ellipsoid, ca. $6 \times 5 \mathrm{~mm}$, red or purple when mature, pubescent with thin appressed dibrachiate reddish-brown trichomes, calyx persistent, seeds 1 or $2,2.2-4.1$ $\times 1.7-3.1 \mathrm{~mm}$.

Myrceugenia euosma is distributed from São Paulo through the Southern states of Brazil and also in Uruguay, Northern Argentina and Southeastern Paraguay, in the Atlantic forest (Landrum 1981; Myrtaceae in BFG 2018). In Santa Catarina it is common in the eastern border of Southern Plateau. This species requires a humid soil and good exposure to light (Legrand \& Klein 1970). Myrceugenia euosma is abundant in the upper highlands of SJNP on river margins, in Araucaria forests and in cloud forests. The species occurrence in SJNP ranges from elevations between $1,380-1,615 \mathrm{~m}$.

Myrceugenia euosma and $M$. regnelliana are very similar when sterile, making it difficult to distinguish them in the field at SJNP. It is possible to separate them by the acuminate to acute leaf apex in M. euosma (vs. acute to rounded in $M$. regnelliana), flower buds with calyx lobes longer than the globe of petals in M. euosma ( $v s$. smaller in $M$. regnelliana), equally pubescent hypanthium and calyx lobes in M. euosma (vs. calyx lobes glabrescent and hypanthium pubescent in M. regnelliana). Two species of parasitic plants were registered in some specimens of M. euosma: Eubrachion ambiguum (Hook. \& Arn.) Engl. (Santalaceae) and Struthanthus uraguensis G.Don
(Loranthaceae). Myrceugenia euosma flowers between October and November. There are records of immature fruits in September and in February, and of mature fruits in November.

Specimens analysed: Bom Jardim da Serra, Morro da

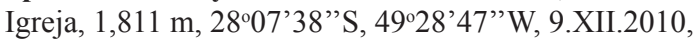
M. Verdi 5858 (FURB). Urubici, Rod. SC-430, $10 \mathrm{~km}$ S de Vacas Gordas, 7.XII.2000, fl., G. Hatschbach et al. 71605 (MBM); Salto Cachoeira do Avencal, lado de cima, 10.XII.2001, fl., G. Hatschbach et al. 72588 (RB); Morro da Igreja, 14.XII.2004, fl., E. Barbosa \& E.M. Cunha 1001 (MBM); trilha do alojamento do ICM-BIO até a Cachoeira, 1,316 m, 28 $08^{\prime} 27.3^{\prime \prime} \mathrm{S}, 49^{\circ} 37^{\prime} 56,8^{\prime \prime} \mathrm{W}$, 07.XII.2013, fl., P. Fiaschi 4064 (FLOR); 1,367 m, 2808'S, 49³7'W, 19.IX.2014, fr., M.A. Wagner \& P. Fiaschi 102 (FLOR); Morro da Igreja, trilha da nascente do rio Pelotas, 1,614 m, $28^{\circ} 08^{\prime} \mathrm{S}, 49^{\circ} 29^{\prime} \mathrm{W}, 20 . I X .2014$, fr., M.A. Wagner \& P. Fiaschi 118 (FLOR); Campos de Santa Bárbara, trilha do italianinho para a parcela PPBio TN0400, 1,382 m, 2808'S, 49³7'W, 21.IX.2014, fr., M.A. Wagner \& P. Fiaschi 125 (FLOR); Morro da Igreja, trilha para a Pedra Furada, $28^{\circ} 07^{\prime} 46^{\prime}$ "S, 49 $28^{\prime} 18^{\prime \prime} \mathrm{W}$, 31.X.2014, fl., M.A. Wagner et al. 131 (FLOR); trilha por trás da Cascata Véu de Noiva, 1,404 m, 2804'40"'S, 49³1'11' 'W, 1.XI.2014, fl. and fr., M.A. Wagner et al. 140 (FLOR); mata nebular, antes da entrada do Sindacta, 1,728 m, 28 07'14"S, 49²9'30”'W, 26.XI.2014, fl., M.A. Wagner et al. 153 (FLOR).

4.4. Myrceugenia miersiana (Gardner) D.Legrand $\&$ Kausel, Comun. Bot. Mus. Hist. Nat. Montevideo 2: 8 (1953).

Fig. 3k

Trees ca. $4 \mathrm{~m}$ high. Young branches flattened, and pubescent. Trichomes yellowish to goldenbrown, nearly all simple, some curled and very thin, erect. Petioles 5-6 × 0.9-1 mm, canaliculate adaxially and densely pubescent on both surfaces; leaf blades 45-60 × 18-26 mm, obovate to elliptic, chartaceous to subcoriaceous, dark green adaxially, lighter green to brownish green abaxially, both surfaces pubescent, more densely so along the midrib, trichomes curled and erect abaxially; base cuneate, apex acute to obtuse; midrib proximal portion canaliculate, distal portion slightly impressed adaxially, distinctly prominent abaxially, secondary veins 6-15 pairs, impressed adaxially, distinctly prominent abaxially, intramarginal vein $0.5-0.8 \mathrm{~mm}$ from the margin, distinctly prominent. Flowers solitary, pedicel $3-5 \times 0.5-0.8 \mathrm{~mm}$, densely pubescent; buds ca. $7 \times 4.3 \mathrm{~mm}$; bracteoles 2.9-4.2 $\times 1-2.1 \mathrm{~mm}$, lanceolate to triangular, keeled, persistent; calyx open in bud, imbricate, lobes 3.7$4.8 \times 3.2-3.9 \mathrm{~mm}$, deltate to widely ovate, slightly concave, pubescent to lanate adaxially, pubescent to lanate abaxially; petals $3.9-5.5 \times 4.3-5.5 \mathrm{~mm}$, 
very widely obovate to circular, ciliate, slightly concave, glabrous adaxially, pubescent abaxially; hypanthium ca. $3 \times 4.7 \mathrm{~mm}$, densely pubescent, shallowly obdeltoid; stamen filaments $2.9-4.8 \times$ 0.1-0.2 mm, anthers $0.5-0.6 \times 0.4-0.5 \mathrm{~mm}$; stigma punctiform, ovary ca. $1.6 \times 1.9 \mathrm{~mm}, 4$-locular, ca. 8 ovules per locule. Berry spheroid, ca. $7 \times 7 \mathrm{~mm}$, dark purple, sparsely pubescent, calyx persistent; seeds 3-4, ca. $5.1 \times 4.5 \mathrm{~mm}$.

This species is distributed in the Atlantic forest of Southern and Southeastern Brazil and also in Bahia (Myrtaceae in BFG 2018). It occurs in Araucaria forests on the eastern edge of Southern Plateau and also in the coastal rainforest, preferentially in high humidity soils and shady environments (Legrand \& Klein 1970; Landrum 1981). In SJNP it occurs in cloud forests at elevations of ca. $1,750 \mathrm{~m}$.

In general Myrceugenia miersiana and $M$. pilotantha are very similar (see steps 14 and 14' of the identification key for characters that separate them). Myrceugenia miersiana flowers in February. Specimens analysed: Urubici, Morro da Igreja, próximo ao alto, 1,750 m, 16.II.1995, fl. G. Hatschbach et al. 61656 (MBM).

Additional material: BRAZIL. PARANÁ: Tijucas do Sul, Matulão, Rio do Fogo 18.IX.1997, fr. J.M. Silva et al. 1971 (FLOR). SANTA CATARINA: Campos Novos, 1,000 m, 11.IV.1963, fl. R. Reitz \& R.M. Klein 14617 (FLOR);

4.5. Myrceugenia myrcioides (Cambess.) O.Berg, Linnaea 27: 134 (1856). Figs. 31-m; 6b-e

Shrubs or trees, 2.5-10 m high. Young branches flattened, pubescent. Trichomes white and reddish-brown, dibrachiate, appressed. Petioles 3-6 × 0.8-1.2 mm, canaliculate adaxially, sparsely pubescent to pubescent on both surfaces; leaf blades 35-110 × 15-36 mm, obovate or elliptic, chartaceous to coriaceous, greyishgreen adaxially, reddish-brown or light green abaxially, sparsely pubescent, especially along midrib adaxially, sparsely pubescent to pubescent abaxially; base attenuate, apex acuminate to acute; midrib canaliculate adaxially, prominent abaxially, secondary veins $12-24$ pairs, impressed adaxially, prominent abaxially, intramarginal vein ca. $1 \mathrm{~mm}$ from the margin. Flowers 1-3 per leaf axil, superimposed on a row in the axil of leaves, pedicel 7-15 × 0.6-1.2 mm, pubescent; buds 5-9 × 3-9 mm; bracteoles $2.2-5 \times 0.7-3$ $\mathrm{mm}$, lanceolate, narrowly triangular or triangular, persistent or caducous; calyx open with lobes exceeding the globe of petals in bud, valvate, lobes $2.5-6 \times 3-4 \mathrm{~mm}$, usually $1.2-2$ times as long as wide, ovate to triangular, concave, glabrous to pubescent adaxially, glabrous to pubescent abaxially; petals 5-8 × 5-8 $\mathrm{mm}$, asymmetrically obovate, concave, glabrous to pubescent towards the apex adaxially, abaxially slightly pubescent to pubescent; hypanthium 3-4× 4-5 mm, pubescent, depressed obovoid to broadly cuneiform; stamen filaments $5.8-10.4 \times 0.1-0.2 \mathrm{~mm}$, anthers $0.5-0.9$ $\times$ 0.4-0.6 mm; stigma punctiform, ovary ca. $2 \times$ $2.5 \mathrm{~mm}, 3-4$-locular, ca. 6 ovules per locule. Berry ellipsoid to spheroid, 11-17 × 5-16 mm, black, purple or grey, pubescent, calyx persistent, seeds $1-2,4-6 \times 2.3-3.5 \mathrm{~mm}$.

This species occurs in the Atlantic forest of Southern and Southeastern Brazil (Landrum 1981; Myrtaceae in BFG 2018). Myrceugenia myrcioides is more abundant in coastal rainforests, but it is also present in Araucaria forests, where it favors moist soils and shady forest environments (Legrand \& Klein 1970). In the upper highlands of SJNP this species is common in high elevations (ca. 1,615 $\mathrm{m}$ ), in cloud forests on the mountainside and in riparian forests.

There are variations in leaf and flower size among individuals of this species in SJNP. Individuals with smaller leaves, ca. $3 \mathrm{~cm}$ long, brownish, pubescent abaxially, buds ca. $5 \times 3 \mathrm{~mm}$, and persistent bracteoles belong to $M$. myrcioides var. myrcioides. Others have longer leaves, ca. 5 cm long, sparsely pubescent, buds 5-9 × 5-9 mm, bracteoles caducous and belong to $M$. myrcioides var. acrophylla (O.Berg) D.Legrand. The two varieties are quite distinct and they occur near each other, In SJNP there are no specimens with characteristics intermediate between the two varieties. Myrceugenia myrcioides flowers in February and bears fruit from July to September. Specimens analysed: Grão Pará, Serra do Corvo Branco, 10.III.2005, fl., G. Hatschbach et al. 78966 (MBM); Orleans, Rio do Meio, $600 \mathrm{~m}$ da vila, 31.XII.1959, fr., $J$. Mattos 7117 (HAS). Urubici, Santo Antônio, 20.I.1960, J. Mattos 7198 (HAS); Serra da Goiabeira, na face voltada para o Rio Canoas, 1,600 m, 22.X.1981, J. Mattos 22767 (HAS); Morro da Igreja, 1,600 m, 19.V.1990, fr., D.B. Falkenberg 5367 (ICN); Rod. SC-430, descida para Águas Brancas, 1,200 m, 7.IV.1991, fr., G. Hatschbach et al. 55323 (MBM); Morro da Igreja, 800 m, 18.VIII.1991, fr., G. Hatschbach \& J.M. Silva 55678 (RB); Salto Véu de Noiva, 14.V.2004, fr., J.M. Silva \& L.R. Lima 4045 (RB); Morro da Igreja, 1,300 m, 14.V.2004, fl., J.M. Silva \& L.R. Lima 4048 (RB); Campo dos Padres, 1,482 m, 27'59'31.9'S, 49²4'43.9'W, 03.IV.2009, fl., M. Verdi et 
al. 1945 (FURB). Santa Terezinha, 1,055 m, 2800'47"S, 49²9'30.9'"W, 7.IV.2009, fr., M. Verdi et al. 1705 (RB!). Xaxim, 27.IV.2009, fr. M. Verdi \& A.L. Gasper 2070 (FURB); próximo à Cascata do Avencal, 1,100 m, 2802'45.9'S, 49³7'00'W, 27.IV.2009, L. Sevegnani, FURB 13696 (FURB); RPPN Leão da Montanha, 1,050 m, 2800'36"S, 49²2'30"W, 8.III.2010, fl., M. Verdi et al. 3800 (FURB); Campos de Santa Bárbara, parcela 3,500, Módulo 1 PPBio, piquete 50, 2809'11' S, 49³8'28'W, 20.V.2014, fr., M.A. Wagner et al. 95 (FLOR); trilha do Morro da Igreja para o Rio Pelotas, $1,614 \mathrm{~m}, 28^{\circ} 08^{\prime} \mathrm{S}$, 49³0'W, 20.IX.2014, M.A. Wagner \& P. Fiaschi 117 (FLOR); 1,587 m, 28 08'04"'S, 49³0'01'”, 11.II.2015, M.A. Wagner et al. 187 (FLOR); 11.II.2015, fl. and fl., M.A. Wagner et al. 189 (FLOR).

4.6. Myrceugenia oxysepala (Burret) D.Legrand \& Kausel, Comun. Bot. Mus. Hist. Nat. Montevideo 2: 5 (1953).

Figs. 3n; 6f-j

Shrubs or small trees 1.5-3 m high. Young branches flattened, sparsely pubescent to pubescent. Trichomes white or reddish-brown, dibrachiate and simple, appressed. Petioles $2-3 \times 0.9-1.1$ $\mathrm{mm}$, canaliculate adaxially, pubescent on both surfaces; leaf blades 21-34 × 8-18 mm, obovate, rarely elliptic, coriaceous, dark green adaxially, light green abaxially, glabrous adaxially, sparsely pubescent, more densely so along the midrib abaxially; base attenuate, apex acute to rounded; midrib canaliculate adaxially, prominent abaxially, secondary veins $8-12$ pairs, impressed adaxially, slightly prominent abaxially, intramarginal vein $0.5-1 \mathrm{~mm}$ from the margin. Flowers solitary, pedicel $1-2 \times 0.8-1.2 \mathrm{~mm}$; buds ca. $4 \times 2.5 \mathrm{~mm}$; bracteoles 4-7 $\times 1.5-2 \mathrm{~mm}$, lanceolate, concave adaxially, persistent; calyx open in bud, valvate, lobes ca. 4 $\times 2.5 \mathrm{~mm}$, lanceolate to triangular, concave and glabrous adaxially, pubescent abaxially; petals ca. $4 \times 3 \mathrm{~mm}$, asymmetrically obovate, concave and glabrous adaxially, glabrous abaxially; hypanthium ca. $2 \times 2 \mathrm{~mm}$, pubescent, broadly obovoid; stamens filaments $3.9-5.1 \times 0.1 \mathrm{~mm}$, anthers $0.4-0.6 \times$ $0.3-0.4 \mathrm{~mm}$; stigma punctiform, ovary ca. $2 \times 2 \mathrm{~mm}$, 2-3-locular, 6 ovules per locule. Berry spheroid, ca. $4 \times 4$, purple when mature, pubescent, calyx persistent in the fruit; seeds 1 or 2 , ca. $2.5 \times 1.5 \mathrm{~mm}$.

Myrceugenia oxysepala is distributed throughout the states of Southern Brazil and in Minas Gerais and São Paulo. However, $M$. oxysepala is more common in the southern part of Santa Catarina state and in Rio Grande do Sul. It is present in the Atlantic forest, in Araucaria forests and cloud forests of the Southern Plateau (Legrand \& Klein 1970; Landrum 1981; Myrtaceae in BFG 2018). In the upper highlands in SJNP, it can be found at elevations between 1,330-1,530 $\mathrm{m}$, in cloud forests, Araucaria forests and riparian forests.

Myrceugenia oxysepala and M. euosma often occur together and could be confused with each other. Myrceugenia oxysepala has larger leaves (21-34 × 8-18 mm long) vs. smaller in $M$. eиosma (13-2 × 4-6 mm long). Flowers appear to be sessile in $M$. oxysepala (peduncle 1-2 $\mathrm{mm}$ long) and in $M$. euosma the peduncle is $5-13$ $\mathrm{mm}$ long. M. oxysepala flowers from November through February and bears fruit from September to November.

Specimens analysed: Bom Jardim da Serra, na boca da Serra Rio do Rastro, 26.III.1981, J. Mattos 22340 (HAS); desfiladeiro do funil, II.1989, fl., M. Sobral et al. 6471 (FLOR). Urubici, Mundo Novo, 1,500 m, 12.XII.1964, fr., J. Mattos 12131 (RB); Morro da Igreja, 4.II.1992, fr., D.B. Falkenberg \& F.A.S. Filho 5869 (FLOR); PPBio parcela TN3500, 1,577.5 m, 2809'11.97'"S, 49³8'30.3'W, 04.III.2014, fl., P. Fiaschi et al. 4188 (FLOR); Campos de Santa Bárbara, estrada para a cachoeira, $1,367 \mathrm{~m}, 28^{\circ} 08^{\prime} \mathrm{S}$, 49³7’W, 19.IX.2014, fr., M.A. Wagner \& P. Fiaschi 103 (FLOR); Campos de Santa Bárbara, trilha do Italianinho, $1,382 \mathrm{~m}, 28^{\circ} 08^{\prime} \mathrm{S}, 49^{\circ} 37^{\prime} \mathrm{W}, 21 . \mathrm{IX} .2014$, fr., M.A. Wagner \& P. Fiaschi 123 (FLOR); Morro da Igreja, trilha da Pedra Furada, 28 $07^{\prime} 46^{\prime \prime}$ S, 49²8'18'W, 31.XI.2014, fr., M.A. Wagner et al. 132 (FLOR); Campos de Santa Bárbara, estrada para a cachoeira, 1,403 m, 28 $08^{\prime} 42^{\prime \prime}$, 49³7'09'W, 9.II.2015, fl., M.A. Wagner et al. 172 (FLOR); Morro da Igreja, trilha para nascente do Rio Pelotas, 11.II.2015, fl. and fl., $28^{\circ} 07^{\prime} 43^{\prime \prime}$ S, 49 $28^{\prime} 20^{\prime \prime} \mathrm{W}$, M.A. Wagner et al. 188 (FLOR).

4.7. Myrceugenia pilotantha (Kiaersk.) Landrum, Brittonia 32: 374 (1980). Fig. 3o Shrub or trees, 1-12 $\mathrm{m}$ high. Young branches flattened, pubescent. Trichomes reddish brown, simple and dibrachiate, appressed. Petioles 4.5-7.5 $\times 0.8-1 \mathrm{~mm}$, pubescent and cylindrical; leaf blades 36-44 × 14-19 mm, obovate to elliptic, chartaceous, dark green adaxially, brownish-green abaxially, very sparsely pubescent, pubescent along midrib adaxially, pubescent, denser along the midrib abaxially, trichomes slightly curled, usually appressed abaxially on leaf blades; base attenuate, apex acute to obtuse; midrib excurrent, canaliculate adaxially, prominent abaxially, secondary veins 11-14 pairs, inconspicuous adaxially, slightly impressed abaxially, intramarginal vein $5-10 \mathrm{~mm}$ from the margin. Flowers solitary, pedicel 3-4 × 8-9 $\mathrm{mm}$, pubescent; buds ca. $5 \times 4 \mathrm{~mm}$; bracteoles ca. 4 $\times 1 \mathrm{~mm}$, narrowly triangular, caducous; calyx open in the bud, valvate, lobes ca. $3.7 \times 4 \mathrm{~mm}$, triangular, 
pubescent on both surfaces; petals ca. $4 \times 4 \mathrm{~mm}$, very widely ovate, concave and glabrous adaxially, pubescent abaxially; hypanthium ca. $2 \times 2 \mathrm{~mm}$, pubescent, broadly obdeltoid; stamens filaments $3.8-8 \times 0.1 \mathrm{~mm}$, anthers $0.4-0.6 \times 0.4-0.5 \mathrm{~mm}$, stigma punctiform, ovary ca. $1.5 \times 1 \mathrm{~mm}, 2$-locular, 6-8 ovules per locule. Berry spheroid to obovoid, ca. $10 \times 7 \mathrm{~mm}$, dark purple, pubescent, calyx persistent in the fruit; 2 or 3 seeds, ca. $4 \times 2.5 \mathrm{~mm}$.

Myrceugenia pilotantha occurs in Bahia, Minas Gerais, Rio de Janeiro, São Paulo, and in the Southern States, in the Cerrado Woodlands and Atlantic forest (Myrtaceae in BFG 2018). This species favors moist soils and elevations between 250 and 1,650 m. It occurs in cloud forests and Araucaria forests, but it seems to be more abundant in coastal rainforests (Landrum 1981; Legrand \& Klein 1970; Myrtaceae in BFG 2018). In the upper highlands of SJNP $M$. pilotantha is found in Araucaria and riparian forests at elevations between 1,350-1,700 $\mathrm{m}$.

Landrum (1981) described M. pilotantha leaf blades as sometimes 3-4 times longer than wide (vs. 2.3 to 2.6 times longer than wide in our study). Myrceugenia pilotantha can be confused with $M$. miersiana, and their differences are summarized under the steps 14 and 14' of the identification key. In SJNP M. pilotantha flowers in January and bears fruits in September.

Specimens analysed: Bom Jardim da Serra, Serra do Rio do Rastro, 1,350 m, 31.I.1985, D.B. Falkenberg \& P.E. Berry 2300 (RB); Desfiladeiro do Funil, 1,700 m, II.1989, fl., M. Sobral et al. 6461 (FLOR). Urubici, Campo dos Padres, 24.I.1957, fl., B. Rambo (PACA 60049); Morro da Igreja, 1,600 m, 24.V.1991, fl. and fr., D.B. Falkenberg 5494 (FLOR); trilha do Morro da Igreja para o Rio Pelotas, 1,614 m, 2808'S, 49³0'W, 20.IX.2014, M.A. Wagner \& P. Fiaschi 114 (FLOR); 20.IX.2014, fr., M.A. Wagner \& P. Fiaschi 115 (FLOR).

4.8. Myrceugenia regnelliana (O.Berg) D.Legrand $\&$ Kausel, Comun. Bot. Mus. Hist. Nat. Montevideo 2: 11 (1953).

Figs. 3j, p-q; 6k-1

Shrubs, treelets and trees, $1-6.5 \mathrm{~m}$ high. Young branches flattened to cylindrical, pubescent. Trichomes white and reddish-brown, simple and dibrachiate, erect and appressed. Petioles $1.3-2.7 \times 0.3-0.9 \mathrm{~mm}$, canaliculate adaxially and pubescent on both surfaces; leaf blades 7-23 $\times$ 2-12 mm, elliptic to obovate, coriaceous, dark green to brownish-green adaxially, lighter green or brownish-green abaxially, glabrous to sparsely pubescent, specially along midrib adaxially, pubescent (younger leaves), to sparsely pubescent (older leaves) abaxially; base attenuate to cuneate, the apex acuminate to acute; midrib slightly canaliculate proximally to impressed distally or slightly canaliculate throughout adaxially, prominent abaxially, secondary veins ca. 10 pairs, inconspicuous adaxially, inconspicuous to slightly prominent abaxially, intramarginal vein $0.1-0.4 \mathrm{~mm}$ from the margin. Flowers solitary, pedicel $2-13 \times 0.2-0.4 \mathrm{~mm}$, sparsely pubescent to pubescent; buds 1.8-3.3 × 1.2-2.1 mm; bracteoles $1.3-1.6 \times 0.4-0.7 \mathrm{~mm}$, ovate, adaxially concave and pubescent proximally, abaxially pubescent and keeled, persistent; calyx open with lobes shorter than the globe of petals in bud, valvate, lobes $1-2 \times$ $1.2-1.6 \mathrm{~mm}$, calyx lobes usually $0.8-1$ time as long as wide, very widely ovate to shallowly deltate, concave and glabrous to sparsely puberulent adaxially, very sparsely pubescent abaxially; petals $1.8-2.7 \times 1.9-3 \mathrm{~mm}$, very widely obovate to circular, concave, glabrous on both surfaces; hypanthium $1.3-1.5 \times 1.1-1.4 \mathrm{~mm}$, densely pubescent, obdeltoid; stamens filament 2.4-4.7 $\times 0.1-0.8 \mathrm{~mm}$, anthers $0.3-0.4 \times 0.3-0.4 \mathrm{~mm}$; stigma punctiform, ovary ca. $0.5-0.9 \times 0.6-0.8$ $\mathrm{mm}, 2$-locular, with 3 to 7 ovules per locule. Berry ellipsoid, 4-9 × 3.4-7.6 mm, dark brown, sparsely puberulent, calyx persistent, seeds $1-4,3-4.5 \times$ 2.2-3.5 mm, embryo myrcioid.

Myrceugenia regnelliana is distributed throughout Southern and Southeastern Brazil, except for the state of Espírito Santo (Myrtaceae in BFG 2018). It grows in the Atlantic forest in cloud forests and Araucaria forests in the eastern part of Southern Plateau. This species favours moist soils (Legrand \& Klein 1970; Landrum 1981; Myrtaceae in BFG 2018) and in the upper highlands of SJNP it occurs in Araucaria forests and on the edges of cloud forests in areas with a good exposure to light, in altitudes between 1,367-1,729 m.

Myrceugenia regnelliana is similar to $M$. acutata, and the characters that differentiate them are discussed in the identification key steps 15 and 15'. The specimens M.A. Wagner 110 and M.A. Wagner 185 are of $M$. regnelliana but present some characteristics that differ from other $M$. regnelliana specimens by presenting golden-brown (vs. white and reddish-brown) trichomes, narrowly elliptic (vs. elliptic to obovate), 3-6 (vs. 2-3.5) times longer than wide leaves, and lanceolate (vs. ovate) bracteoles. These differences might be due to these specimens occurrence fully exposed to sunlight. In the upper highlands of SJNP M. regnelliana flowers and fruits between September and November. 
Specimens analysed: Bom Jardim da Serra, 1,300 m, 31.I.1985, fr., D.B. Falkenberg \& P.E. Berry 2301 (RB). Urubici, Mundo Novo, 1,500 m, 12.XII.1964, fl., J. Mattos 12134 (RB); Morro da Igreja, próximo ao alto, 1,650 m, 18.X.2004, G. Hatschbach 78199 (RB). Santo Antônio, 01.I.2010, L. Sevegnani (FURB 33937); Campos de Santa Bárbara, PPBio módulo 1, parcela TN350, 1,577.6 m, 2809'12'"S, 49³8'30.3'W, 04.III.2014, fl., P. Fiaschi et al 4176 (FLOR); Campos de Santa Bárbara, estrada para a cachoeira, 1,367 m, 2808'S, 49³7'W, 19.IX.2014, fl. and fr., M.A. Wagner $\&$ P. Fiaschi 100 (FLOR); Morro da Igreja, estrada da antena, 1,729 m, 2807'S, 49²9' W, 20.IX.2014, fl. and fr., M.A. Wagner \& P. Fiaschi 107 (FLOR); trilha para Rio Pelotas, 1,614 m, 2808'S, 49³0'W, 20.IX.2014, fr., M.A. Wagner \& P. Fiaschi 112 (FLOR); Morro da Igreja, trilha da Pedra Furada, 28 $07^{\circ} 46^{\prime}$ 'S, 49²8'18' W, 31.X.2014, fl. and fl., M.A. Wagner et al. 133 (FLOR); mata nebular antes do portão do Sindacta, $1,728 \mathrm{~m}$, 2807'14"'S, 49²9'30"'W, 31.X.2014, fr., M.A. Wagner et al. 137 (FLOR); Morro da Igreja, trilha nascente do Rio Pelotas, 1,651 m, 2807'52'S, 49'29'57' W, 11.II.2015, fl. and fl., M.A. Wagner et al. 186 (FLOR!).

5. Myrcia DC. Dict. Class. Hist. Nat. 11: 406 (1827).

Shrubs or trees. Trichomes simple or dibrachiate. Inflorescence panicles; bracteoles caducous; calyx open in bud; lobes 4-5; petals 4-5, white, membranous; stamens 20-320, flexible, white; hypanthium shallowly obpyramidal or very widely obovoid, not prolonged above the ovary, ovaries $2-3(-4)$ locular, with 2 ovules per locule. Berry spheroid, seeds 1-4 or more, embryo myrcioid, cotyledons thin, leafy, folded into a bundle, hypocotyl cylindrical, narrow, as long as the cotyledons.

The distribution of Myrcia is from Mexico and the Caribbean throughout South America to Northern Argentina (Landrum \& Kawasaki 1997). There are approximately 260 species of Myrcia in Brazil (Myrtaceae in BFG 2018).

\subsection{Myrcia aethusa (O.Berg) Silveira, Roessleria 7: 67 (1985). \\ Fig. $4 \mathrm{a}$}

Shrubs or trees, 4-10 $\mathrm{m}$ high. Young branches flattened, densely pubescent. Trichomes white, yellowish or reddish-brown, simple, slender. Petioles $3.3-5 \times 0.9-1.3 \mathrm{~mm}$, canaliculate adaxially, pubescent on both surfaces; leaf blades 35-43 × 11-15 mm, lanceolate to narrowly elliptic, chartaceous to subcoriaceous, dark reddish-brown adaxially and light yellowish-brown abaxially, pubescent along the midrib adaxially, sparsely pubescent throughout the blade, pubescent along the midrib, densely pubescent when leaves are very young abaxially; the base attenuate to cuneate, apex acuminate or caudate; midrib canaliculate proximally to impressed distally adaxially, prominent abaxially, secondary veins ca. 15 pairs, impressed adaxially, slightly prominent abaxially, intramarginal vein 0.4 to $0.9 \mathrm{~mm}$ from the margin. Inflorescence a dichasium or a panicle with 3-15 flowers, inflorescence peduncle 12.1-15.4 $\times 0.5-0.6 \mathrm{~mm}$, glabrous to sparsely pubescent, pedicels $4.1-6.2 \mathrm{~mm}$; buds $2-3.3 \times 1.9-3.1 \mathrm{~mm}$; bracteoles 1-2.5 × $0.4 \mathrm{~mm}$, lanceolate, ciliate, sparsely pubescent and slightly concave adaxially, keeled abaxially, caducous; calyx imbricate, lobes $5,0.8-1.3 \times 1.4-1.8 \mathrm{~mm}$, shallowly triangular, ciliate in the margins, pubescent adaxially, glabrous abaxially; petals 5, 3.4-3.6 $\times 2.2-2.3 \mathrm{~mm}$, obovate, glabrous on both surfaces; hypanthium ca. 1.8 $\times 2.7 \mathrm{~mm}$, glabrous, shallowly obpyramidal; stamens filaments $1.9-4.7 \times 0.1 \mathrm{~mm}$, anthers 0.4 $\times 0.3-0.4 \mathrm{~mm}$, thecal arrangement parallel; stigma punctiform, ovary ca. $0.7 \times 0.9 \mathrm{~mm}, 3$-locular. Berry spheroid, 5.5-8.6 $\times 5.5-8.6 \mathrm{~mm}$, dark purple when mature, glabrous, calyx persistent; seeds $1-3$, $\times 3.5-5.4 \mathrm{~mm}$.

Myrcia aethusa occurs in all states of Southern and Southeastern Brazil in the Atlantic forest (Myrtaceae in BFG 2018). It can be found in cloud forests and it is abundant in the rainforest of the Atlantic slopes. This species seems to be rare in the upper highlands of SJNP. There is one record of $M$. aethusa near the highway SC 370 towards Grão Pará at 1,040 m. This highway passes very close to the northern border of SJNP. Legrand \& Klein (1969b) describe it as a species present on steep slopes, so there is high probability that Myrcia aethusa is more abundant on the high declivity slopes of SJNP facing the Atlantic, along the Planalto escarpment, areas of difficult access for collection. The species favors slightly moist soils and good sunlight exposition (Legrand \& Klein 1969b; Myrtaceae in BFG 2018).

Specimens analysed: Grão Pará, beira da estrada SC439, em direção a Grão Pará, parte baixa de um vale, pouco antes da borda da Serra Geral, 1,040 m, 12.I.1987, fl., D.B. Falkenberg et al. 4308 (FLOR!).

Additional material: BRASIL. SANTA CATARINA: Florianópolis, morro costa da Lagoa da Conceição, 300 m, 17.I.1967, fl., R.M. Klein 7098 (FLOR). Governador Celso Ramos, Jordão, 300 m, 16.XI.1971, fl., R.M. Klein 9891 (FLOR). Palhoça, Morro do Cambirela, $800 \mathrm{~m}$, 22.IX.1971, fr., R.M. Klein \& A. Bresolin 9741 (FLOR). 


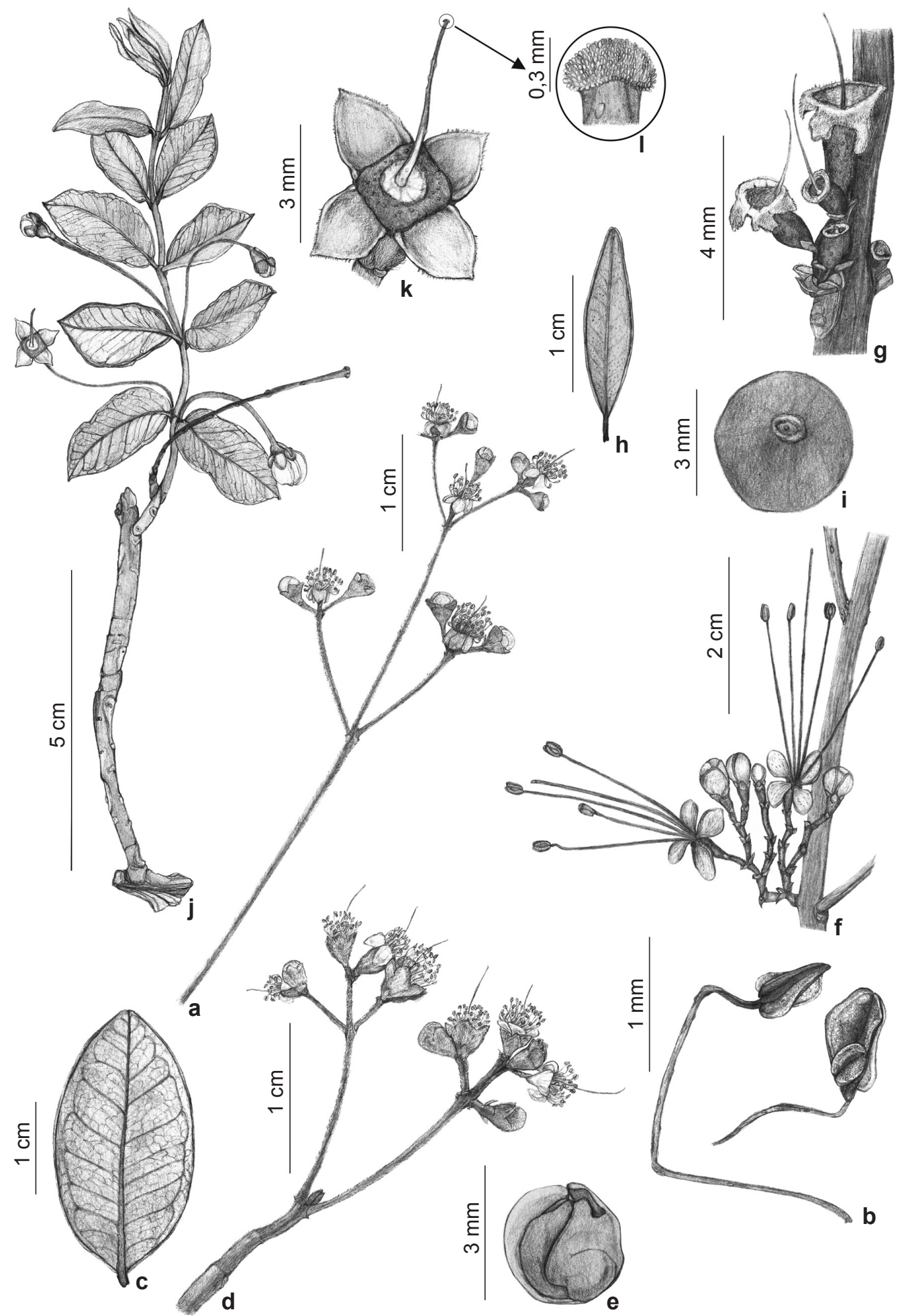

Figure 4 - a. Myrcia aethusa - panicle. b-e. Myrcia hartwegiana - b. stamens; c. leaf, abaxial surface; d. panicle; e. myrcioid embryo. f. Myrrhinium atropurpureum - dichasium on short bracteate shoot. g-i. Siphoneugena reitzii - g. fascicle; h. leaf, abaxial surface; i. fruit. j-1. Psidium salutare - j. branch with buds and flowers; k. flower; 1. peltate stigma. (a. R.M. Klein 7098; b, d. A. Bresolin 698; c, e. M.A. Wagner 142; f. M. Grizzon 212; g. A. Bresolin 547; h, i. M.A. Wagner 139; j-1. E. Richetti 1). 
5.2. Myrcia hartwegiana (Berg) Kiaersk., Enum. Myrt. Bras.: 109 (1893).

Fig. 4b-e

Small trees, ca. $2 \mathrm{~m}$ high. Young branches flattened, pubescent near the apex, sparsely pubescent to glabrous towards the base of the branch. Trichomes white or reddish-brown, simple. Petioles 2-4 × 0.9-1.4 mm, canaliculate adaxially, pubescent on both surfaces; leaf blades 23-55 $\times$ 11-18 mm, obovate to elliptic, chartaceous, dark brownish-green adaxially, light brownish-green abaxially, sparsely pubescent to glabrous adaxially, sparsely pubescent, denser along midvein to glabrous abaxially; base attenuate to cuneate, apex rounded; midrib canaliculate proximally, impressed distally adaxially, prominent abaxially, secondary veins $8-10$ pairs, slightly impressed adaxially, invisible to prominent abaxially, intramarginal vein prominent, $0.8-1.2 \mathrm{~mm}$ from the margin. Inflorescence a panicle subtended by caducous bracts in the axil of leaves, with 8 to 10 flowers; peduncle $8-18 \times 0.5-0.7 \mathrm{~mm}$, pubescent; pedicels $0.5-1 \mathrm{~mm}$; buds $2.1-2.2 \times 2 \mathrm{~mm}$; bracteoles $1.5-2$ $\times 0.8-0.9 \mathrm{~mm}$, trullate, caducous; calyx imbricate, lobes 5, 0.8-1.1 × 1.1-1.9 mm, shallowly triangular, pubescent on both surfaces; petals 5, 3-3.7 × 2-3 $\mathrm{mm}$, very widely obovate, concave and glabrous adaxially, pubescent abaxially; hypanthium $1.5-2 \times 1.5-2.5 \mathrm{~mm}$, densely pubescent, very widely obovoid; stamens with filaments 33-38 $\times 1 \mathrm{~mm}$; anthers $0.7-0.8 \times 0.3-0.4 \mathrm{~mm}$; vertical displacement of thecae, pollen sacs of anthers at slightly different levels; stigma punctiform, ovary $0.6-1 \times 0.8-1.1 \mathrm{~mm}, 2$-locular. Berry spheroid, ca. $4 \mathrm{~mm}$ in diameter, pubescent, calyx persistent; seed 1, 2-3 $\times 3 \mathrm{~mm}$, embryo myrcioid.

Myrcia hartwegiana is distributed in all states of Southern and Southeastern Brazil except for Espírito Santo (Myrtaceae in BFG 2018). It occurs in the Atlantic forest in Araucaria forests, in the coastal rainforests and in the Planalto Merdional it is an important species in capões (typical vegetation in Southern Brazil formed by an assemblage of trees surrounded by grasslands) (Legrand \& Klein 1967). In the upper highlands of SJNP it occurs at elevations closer to $1,000 \mathrm{~m}$, it is uncommon in higher elevations.

Specimens analysed: Urubici, salto Cachoeira do Avencal, lado de cima, 10.X.2001. G. Hatschbach et al. 72594 (RB); trilha por trás da Cascata Véu de Noiva, 1,404 m, 2804'40"'S, 49³1'11'”W, 1.XI.2014, fr., M.A. Wagner et al. 142 (FLOR).

Additional material: BRAZIL. SANTA CATARINA: Benedito Novo, nascentes do Rio Zinco, Alto Benedito, 750 m, 8.II.1973, fl., A. Bresolin \& Roco 698 (FLOR).

\section{Myrrhinium Schott}

Myrrhinium is a monotypic genus with a wide geographic distribution, from Rio de Janeiro to Uruguay and Northern Argentina, reaching Colombia through the Andes (Landrum 1986).

6.1. Myrrhinium atropurpureum Schott, Syst. Veg. (ed. 16) 4(2): 404 (1827). $\quad$ Fig. 4f

Shrub or trees, $2-5 \mathrm{~m}$ high. Young branches flattened to cylindrical, glabrous to pubescent. Trichomes white, simple. Petioles 2.2-4.2 $\times$ $0.8-1.2 \mathrm{~mm}$, glabrous; leaf blades 3.2-49 × 11-19 $\mathrm{mm}$, narrowly elliptic or elliptic, coriaceous, bright green adaxially, lighter green abaxially, glabrous on both surfaces, with very small puctuations on abaxial surface; base attenuate, apex acuminate; midrib impressed adaxially, prominent abaxially, secondary veins ca. 10 pairs, slighlty impressed adaxially, inconspicuous to slightly impressed abaxially, intramarginal vein 0.4 to $0.8 \mathrm{~mm}$ from the margin. Inflorescence a dichasium, peduncle $1.8-7.5 \times 0.8-2.2 \mathrm{~mm}$, glabrous, pedicel ca. 1.8 $\mathrm{mm}$; buds 3.2-4.8 $\times 1.8-2.4 \mathrm{~mm}$; bracteoles ca. $0.9 \times 0.9 \mathrm{~mm}$, triangular; calyx open in bud; calyx valvate, lobes $0.7-0.9 \times 1.5-1.7 \mathrm{~mm}$, shallowly triangular, glabrous adaxially, ciliolate, glabrous abaxially; petals fleshy, ca. $5.1 \times 4.1 \mathrm{~mm}$, widely obovate, glabrous on both surfaces; hypanthium ca. $2.6 \times 1.6 \mathrm{~mm}$, glabrous, obconic, not prolonged above ovary, superseded by calyx lobes; stamens 4-8, red, filaments stiff, $6.7-16.9 \times 0.3-0.5 \mathrm{~mm}$, anthers $1.5-1.9 \times 0.5-0.8 \mathrm{~mm}$, thecal arrangement parallel; stigma punctiform, ovary ca. $2 \times 1.1$ $\mathrm{mm}$, ca. 9 ovules per locule. Berry spheroid, ca. $4.9 \times 4.8 \mathrm{~mm}$, green when immature, glabrous, calyx persistent, seeds $3,3.5 \times 2.8 \mathrm{~mm}$. Embryo myrtoid, c-shaped, hypocotyl and cotyledons equal in length.

In Brazil, Myrrhinium atropurpureum is distributed in Southern Brazil, and in São Paulo, Rio de Janeiro and Espírito Santo, in the Atlantic forest and in the Pampa Grasslands (Myrtaceae in BFG 2018). It occurs on the edges of Araucaria forests. In the upper highlands of SJNP $M$. atropurpureum is not an abundant species.

In the upper highlands of SJNP $M$. atropurpureum flowers in September and October. Specimens analysed: Urubici, Rio dos Bugres, 950 m, 11.XI.2001, fl., G. Hatschbach et al. 72644 (MBM); Pousada Arroio da Serra, 880 m, 27057'20"'S, 49³8'60"W, 25.X.2011, fl., L. Sevegnani 10 (FURB); trilha do alonjamento ICM-BIO até a Cachoeira, 1,366 m, $28^{\circ} 08^{\prime} 30,9^{\prime \prime}$ 'S, 49³8'07,7'”W, 3.IX.2013, fl., P. Fiaschi et al. 3976 (FLOR!). 


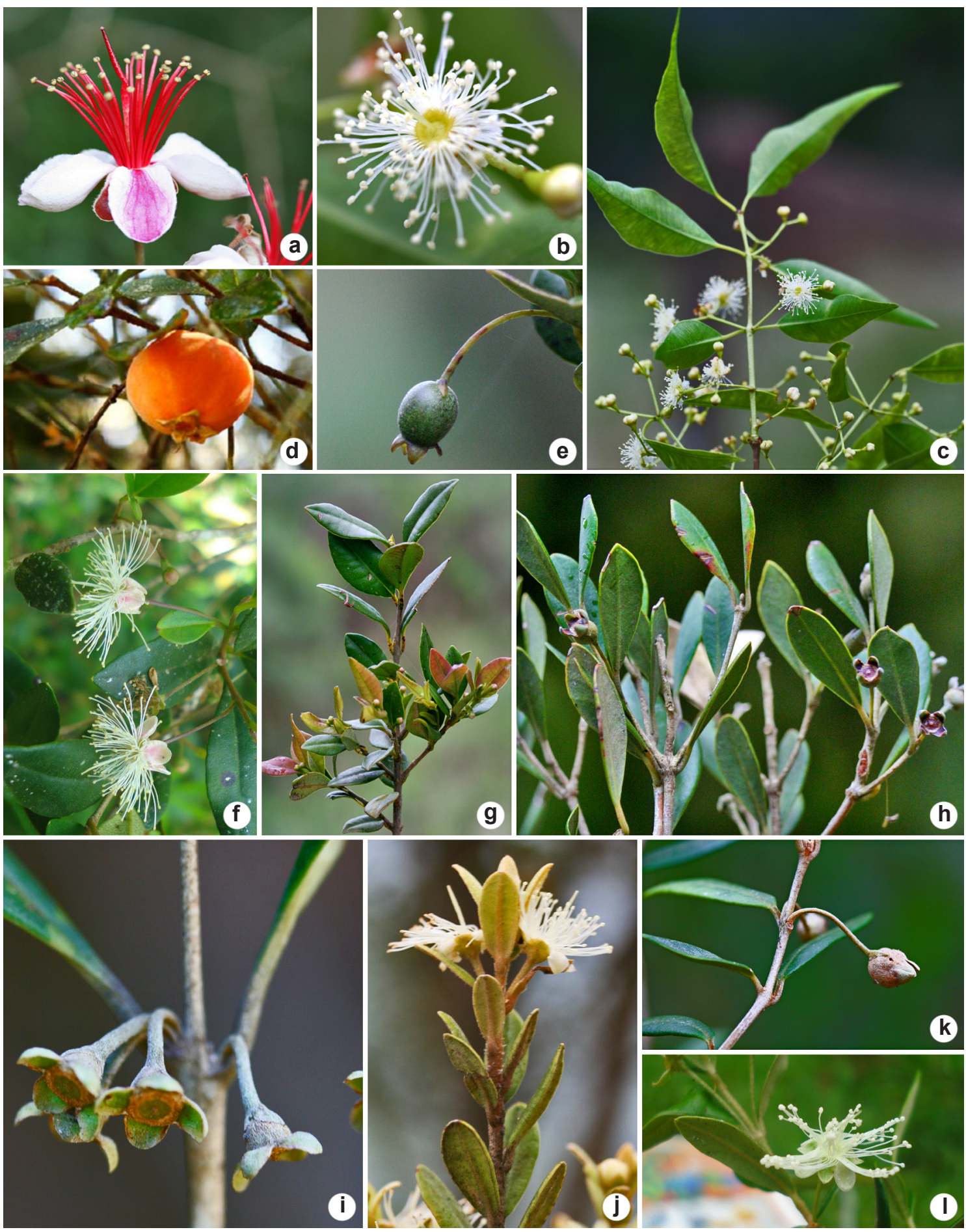

Figure 5 - a. Acca sellowiana - flower. b-c. Blepharocalyx salicifolius - b. flower; c. branch with leaves, flowers and buds. d. Eugenia handroi - fruit. e-g. Myrceugenia acutata - e. fruit; f. flowers; g. branch with leaves and buds. h-i. Myrceugenia alpigena - h. branch with leaves and immature fruits; i. flowers disposed on a row on the axil of a leaf. j-1. Myrceugenia euosma - j. branch with leaves and flowers; k. fruit; 1. flower. (Photographs: a-c, e, g-k. $P$. Fiaschi; d. E.S. Alves; f, 1. M.A. Wagner). 


\section{Psidium L.}

Psidium comprises about $70 \mathrm{spp}$. from the American tropics (Wilson 2011).

7.1. Psidium salutare (Kunth) O.Berg, Linnaea 27: 356 (1856).

Figs. $4 \mathrm{j}-1 ; 6 \mathrm{a}$

Subshrubs with underground main shoot from where branches branch out, $20-40 \mathrm{~cm}$ long. Young branches flattened, grooved, densely pubescent. Trichomes simple. Petioles 1.9-2.7 × 0.7-0.9 mm, canaliculate adaxially, pubescent on both surfaces; leaf blades 12-24 × 8-14 mm, elliptic to obovate, coriaceous, light green on both surfaces, densely pubescent when young, sparsely pubescent when older adaxially, very small punctuation visible on abaxial surface; base cuneate, apex acute; midrib slightly canaliculate proximately to slightly prominent distally adaxially, prominent abaxially, secondary veins $7-8$ pairs, prominent adaxially on both surfaces, intramarginal vein $0.3-0.6 \mathrm{~mm}$ from the margin. Flowers solitary, 4 bracts, ca. $1 \mathrm{~mm}$ long, lanceolate, pedicel 15.2-27.8 $\times 0.5-0.7 \mathrm{~mm}$, pubescent; buds ca. 3.7-5.8 $\times 2.7-4 \mathrm{~mm}$; bracteoles $4.8-5.9 \times 0.6-0.9$, oblanceolate; calyx open in bud, lobes 4-5, 2.6-3.4 × 2.2-3.1 mm, deltate, ciliate, glabrous to slightly pubescent distally adaxially, glabrous abaxially; petals membranous, $4-5$, ca. 6.2 $\times 5.7 \mathrm{~mm}$, very widely obovate, glabrous adaxially and abaxially; hypanthium not prolonged above the ovary, ca. $2.6-3.2 \times 2.2-2.5 \mathrm{~mm}$, lanuginose, obdeltoid; stamens ca. 130, white, filaments flexible, $1.7-3.2 \times 0.2-0.3 \mathrm{~mm}$, anthers $0.6-0.9 \times$ $0.5-0.8 \mathrm{~mm}$, thecal arrangement parallel; stigma peltate, ovary ca. $1.2 \times 1.3 \mathrm{~mm}, 2-3$ locular, ca. 8-10 ovules per locule. Berry ellipsoid. Embryo myrtoid, c-shaped, hypocotyl much longer than cotyledons.

Psidium salutare occurs in Southern Brazil, in São Paulo, Minas Gerais, Bahia, Goiás, Mato Grosso and Pará, in the Caatinga scrubland, in grasslands, rocky outcrops, in the Araucaria forests and Cerrado woodlands (Myrtaceae in BFG 2018). It occurs in areas with good exposure to sunlight and in rocky outcrops, usually in open grasslands or on mountain sides (Legrand \& Klein 1977).

Psidium salutare was seen in the highlands of SJNP, but unfortunately was not collected because only vegetative material was available. The material analyzed here was collected in the municipality of São Joaquim (SC), in an elevation of $1,200 \mathrm{~m}$, in rocky outcrops. Psidium salutare flowers in March.
Specimens analysed: São Joaquim, Comunidade Despraiado, 1,200 m, 17.III.2016, fl. and fl., E. Richetti 1 (FLOR).

\section{Siphoneugena O. Berg.}

Siphoneugena is dispersed from the Caribbean throughout South America to Southern Brazil (Landrum \& Kawasaki 1997). In Brazil there are 9 species of the genus (Myrtaceae in BFG 2018).

8.1. Siphoneugena reitzii D.Legrand, Sellowia 8: 78 (1957b).

Fig. 4g-i

Shrubs or trees, 1.8 to $10 \mathrm{~m}$ high. Young branches slightly flattened, sparsely puberulent to puberulent. Trichomes white. Petioles 2.5-3.2 $\times 0.6-0.7 \mathrm{~mm}$, canaliculate adaxially, pubescent on both surfaces; leaf blades 17-29 × 5-10 mm, narrowly elliptic, chartaceous, darker brownishgreen adaxially, lighter brownish-green abaxially, glabrous to sparsely pubescent, specially along midrib adaxially, glabrous abaxially, punctuations very small dots on abaxial surface; base attenuate, apex acuminate; midrib impressed adaxially, prominent abaxially, secondary veins $10-14$ pairs, inconspicuous adaxially, slightly impressed abaxially, intramarginal vein $0.2-0.3 \mathrm{~mm}$ from the margin. Inflorescence usually a bracteate shoot, 1-3 flowers, bracts lanceolate, $1 \mathrm{~mm}$ long, inflorescence peduncle $1.7-2 \times 0.5-0.7 \mathrm{~mm}$, glabrous, flower pedicel $1 \mathrm{~mm}$ long; buds ca. $4 \times 1.8 \mathrm{~mm}$; bracteoles ca. $0.5 \times 0.5 \mathrm{~mm}$, deltate, persistent; calyx closed in bud, lobes form a tubular structure continuous from the hypanthium, which is deciduous after anthesis lobes ca. $1 \times 1.3 \mathrm{~mm}$, square, puberulent adaxially, puberulent on the margins abaxially; petals ca. $1.2 \times$ $1.6 \mathrm{~mm}$, very widely obovate, puberulent adaxially, glabrous abaxially; hypanthium ca. $3.3 \times 1.5 \mathrm{~mm}$, glabrous, oblong to obovoid; stamens filaments $1.7-3.8 \times 0.1 \mathrm{~mm}$, anthers $0.3-0.4 \times 0.3 \mathrm{~mm}$, thecal arrangement parallel; stigma punctiform, ovary ca. $1.3 \times 1.2 \mathrm{~mm}, 3-4$ locular. Berry circular, ca. $4 \times 5 \mathrm{~mm}$, red, glabrous, seed 1 , ca. $3.6 \times 3.6 \mathrm{~mm}$. Embryo eugenioid, with two separate plano-convex cotyledons.

Siphoneugena reitzii is distributed through Southern and Southeastern Brazil in the Atlantic forest (Legrand \& Klein 1977; Myrtaceae in BFG 2018). In the upper highlands of SJNP Siphoneugena reitzii was collected at an elevation of approximately $1,000 \mathrm{~m}$. The species is not abundant in SJNP.

Siphoneugena reitzii bears fruit in November in the upper highlands of SJNP. 


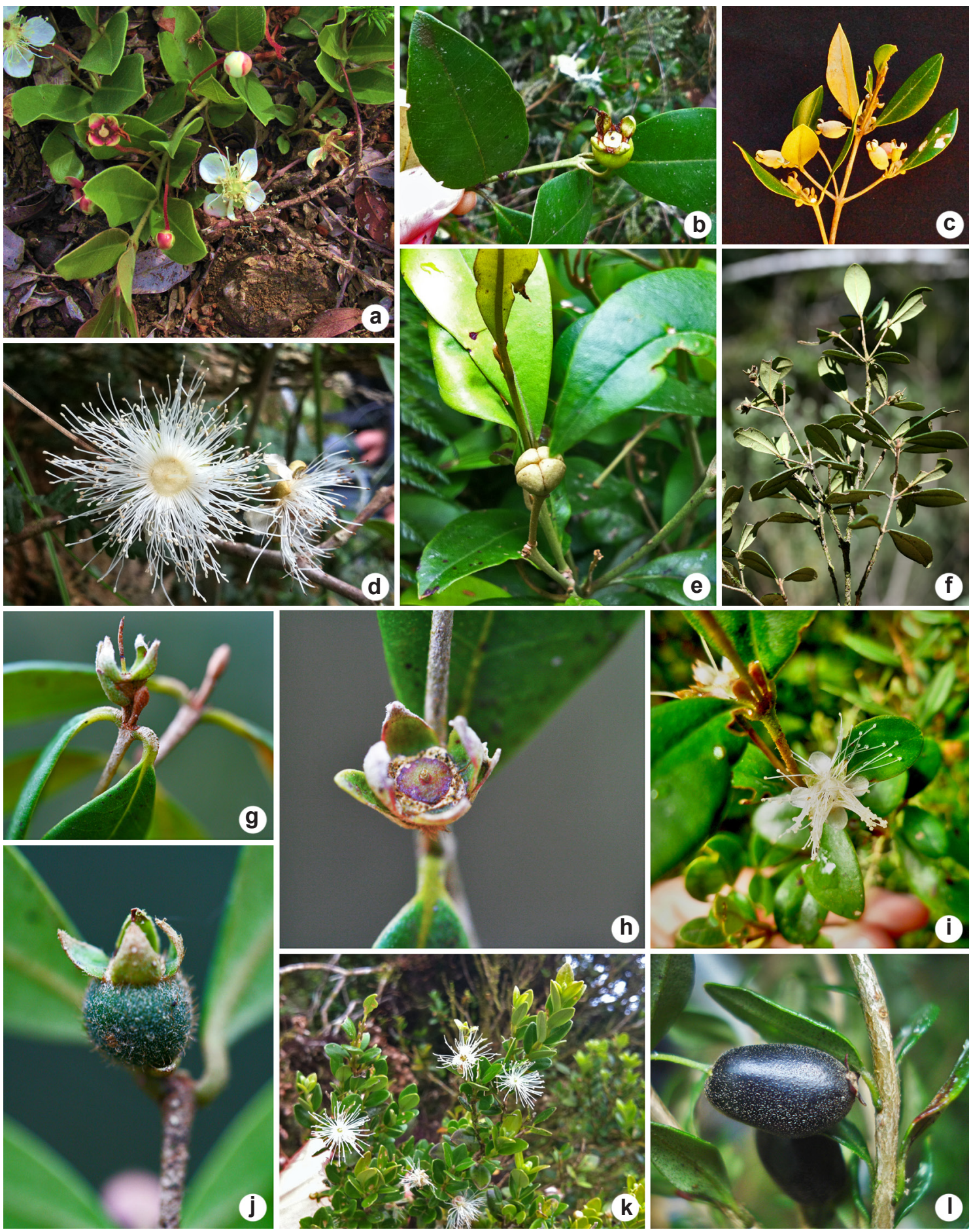

Figure 6 - a. Psidium salutare - branch with flowers and buds. b-e. Myrceugenia myrcioides - b. fruit; c. branch with leaves and fruits; d. flowers; e bud. f-j. Myrceugenia oxysepala - f. branch with leaves and fruit; g-i. flower with calyx lobes and bracteoles; j. fruit. k-1. Myrceugenia regnelliana - k. branch with flowers and leaves; 1 . fruit. (Photographs: a. E. Richetti; b, d, e, k, 1. M.A. Wagner; c. J. Silveira; f-h, j. P. Fiaschi; i. M. Palacio). 
Specimens analysed: Urubici, Xaxim, 1,811 m, 2807'38' S, 49²8'47'W, 27.IV.2009, M. Verdi \& A.L. Gasper 2062 (FURB); 1-1,5 km a sudeste do topo do Morro da Igreja, ao longo do afluente do Rio do Bispo, $1,700 \mathrm{~m}, 28^{\circ} 08^{\prime} \mathrm{S}, 4^{\circ} 28^{\prime} 30^{\prime \prime} \mathrm{W}, 22$.VII.2014, fr., D.B. Falkenber 7992 (FLOR); Morro da Igreja, trilha por trás da cascata véu de noiva, 1,404 m, 2804'40"'S, 49³1'11''W, 1.XI.2014, fr., M.A. Wagner et al. 139 (FLOR).

Additional material: BRAZIL. SANTA CATARINA: Palhoça, Morro do Cambirela, 850 m, 5.IV.1972, fl., A. Bresolin 547 (FLOR).

\section{Concluding remarks}

The species of Myrtaceae that occur in the highlands of SJNP present the following patterns of geographic distribution: Acca sellowiana, for example, has a distribution mostly restricted to Southern Brazil and Uruguay (Landrum 1986). There are records of $A$. sellowiana in Rio de Janeiro, São Paulo and Paraná (Myrtaceae in BFG 2018), however, these records are sporadic, and probably of cultivated specimens.

Myrceugenia acutata, $M$. euosma, $M$. myrcioides, $M$. oxysepala, $M$. regnelliana, Myrcia aethusa, M. hartwegiana, Myrrhinium atropurpureum, and Siphoneugena reitzii present a distribution throughout the states of Southern and Southeastern Brazil. Myrceugenia euosma also occurs in Northern Argentina and Southeastern Paraguay. Blepharocalyx salicifolius, M. alpigena, M. miersiana, and M. pilotantha have a wider distribution, occurring not only in the South and Southeast of Brazil but also in the Central-West, Northeast, and North regions of the country (Myrtaceae in BFG 2018).

Compared to other high montane areas from Southern and Southeastern Brazil, Myrtaceae richness at SJNP is lower than in areas at lower latitudes, such as the highlands of Quiriri Range in Garuva, northern Santa Catarina, where Vieira (2010) registered 10 genera and 26 species of Myrtaceae: Myrceugenia (7 spp.), Myrcia (7 spp.), Eugenia (4 spp.), Psidium (2 spp.), Siphoneugena (1 sp.), Blepharocalyx (1 sp.), Calyptranthes Sw. (1 sp.), Myrciaria O.Berg (1 sp.), Pimenta Lindl. (1 sp.), and Plinia L. (1 sp.). Quiriri Range is located in the southern portion of Serra do Mar Range formation, in the northern part of Santa Catarina and the upper highlands of SJNP are situated on the Serra Geral Range formation in the southern part of the state. Compared to that study, the absence of Calyptranthes, Myrciaria, Pimenta, and Plinia at SJNP might be explained by the existence of the
Serra Geral Range, which, according to Legrand (1962), acts as a barrier for the distribution of the tropical Myrtaceae.

Mattos (1957) presented a list of 12 genera and 24 species of Myrtaceae from the municipality of São Joaquim, which at that time included part of SJNP with in its limits. Urubici and Bom Jardim da Serra were separated from São Joaquim and became independent municipalities later in 1957 and in 1962, respectively. The Park's higher elevations now lie in Urubici and Bom Jardim da Serra, and no part of SJNP now falls within São Joaquim municipality. This list from Mattos (1957) included Myrceugenia (7 spp.), Myrcia (4 spp.), Campomanesia Ruiz \& Pav. (2 spp.), Eugenia (2 spp.), Myrcianthes O.Berg (2 spp.), Acca (1 sp.), Blepharocalyx (1 sp.), Calypthrantes (1 sp.), Myrciaria (1 sp.), Myrrhinium (1 sp.), Psidium (1 sp.) and Siphoneugena (1 sp.), but Campomanesia, Myrcianthes and Myrciaria have not been recorded in our study in the upper highlands of SJNP. This may be due to the long distance (ca. $95 \mathrm{~km}$ ) separating the municipality from the park limits.

Myrceugenia is the richest genus of Myrtaceae in the upper highlands of SJNP, in the Quiriri Range (Vieira 2010), and in the municipality of São Joaquim (Mattos 1957). It includes ca. 40 species with a disjunct distribution in South America (14 species in Chile and Argentina and the remaining in eastern South America, Landrum 1981). The eastern Myrceugenia clade diverged from the Chilean one about 20 Ma ago in the Miocene (Murillo-A et al. 2016), and diversified in Southern and Southeastern Brazil, at present occupying areas in the Atlantic forest, the Cerrado woodlands and the Pampas temperate grasslands (Murillo-A et al. 2016). This diversification was higher than expected at random for Myrceugenia and Myrtaceae in subtropical regions of South America (Giehl \& Jarenkow 2012), emphasizing the importance of these sites as centers of Myrtaceae diversity and endemism.

Myrtaceae is one of the richest tree families in the Atlantic forest (BFG 2018), and an important component of São Joaquim National Park upper highlands flora. Although tropical areas are usually richer in species of Myrtaceae, genera like Myrceugenia appear to be a more important element of subtropical and highland areas. To understand how the species composition of the family varies along a latitudinal gradient in the Atlantic Forest, an investigation of the evolutionary history and ecological drivers of Myrtaceae diversity would be desirable. 


\section{Acknowledgements}

We thank Diogo Chicatto for the illustrations, and Genivaldo Alves da Silva, Jonnhy Silveira, Mayara Caddah and Melissa Palacio for helping with field expeditions. We also thank CAPES for the funding and UFSC for funding and infrastructure to make this project possible. We thank PPBio Mata Atlântica and SJNP for the support. PF thanks $\mathrm{CNPq}$ for the Research Productivity Scholarship (PQ 306228/2016-5).

\section{References}

Alarcon GG \& Silva EH (2007) Mapeamento e caracterização da cobertura vegetal e uso do solo do Parque Nacional de São Joaquim, SC. Revista Discente Expressões Geográficas 3: 121-141.

Berg O (1855) Revisio Myrtacearum Americae. Linnaea 27: 1-128.

Berg O (1856) Revisio Myrtacearum Americae. Linnaea 27: 129-512.

Berg O (1857) Myrtaceae. In: Martius CFP (ed.) Flora brasiliensis. R. Oldenburg, Munich and Leipzig, Vol. 14, Pars I, pp. 1-468.

Berg O (1858-1859) Myrtaceae. In: Martius CFP (ed.) Flora brasiliensis. R. Oldenburg, Munich and Leipzig, Vol. 14, Pars I, pp. 469-575.

BFG - The Brazil Flora Group (2018) Brazilian Flora 2020: innovation and collaboration to meet Target 1 of the Global Strategy for Plant Conservation (GSPC). Rodriguésia 69: 1513-1527.

Candolle AP (1827) Dictionaire classique d'histoire naturelle. Vol. 11. Rey et Gravier, Paris. 406p.

Falkenberg DB \& Voltolini JC (1995) The Montane Cloud Forest in Southern Brazil. In: Hamilton LS, Juvik JO \& Scaten FN (eds.) Tropical montane cloud forests. Ecological Studies 110. Springer Verlag, New York. Pp. 138-149.

Falkenberg DB (2003) Matinhas nebulares e vegetação rupícola dos Aparados da Serra Geral (SC/RS), Sul do Brasil. Universidade Estadual de Campinas, Campinas. 558p.

Faria JEQ (2010) O gênero Eugenia L. (Myrtaceae) nos estados de Goiás e Tocantins. Dissertação de Mestrado. Universidade Federal de Brasília, Brasília. 266p.

Gasper AL, Sevegnani L, Vibrans AC, Sobral M, Uhlmann A, Lingner DV, Rigon-Júnior MJ, Verdi M, Stival-Santos A, Dreveck S \& Korte A (2013) Inventário florístico florestal de Santa Catariana: espécies da Floresta Ombrófila Mista. Rodriguésia 64: 201-210. doi: <http://dx.doi.org/10.1590/S2175$78602013000200001>$.

Giehl ELH \& Jarenkow JA (2012) Niche conservatism and the differences in species richness at the transition of tropical and subtropical climates in
South America. Ecography 35: 933-943. doi <http:// dx.doi.org/10.1111/j.1600-0587.2011.07430.x>.

Hamilton LS, Juvik JO \& Scatena FN (1995) The Puerto Rico tropical cloud forest symposium: introduction and workshop synthesis. In: Hamilton LS, Juvik JO \& Scaten FN (eds.) Tropical montane cloud forests. Ecological Studies 110. Springer Verlag, New York. Pp. 1-24.

Higuchi P, Silva AC, Ferreira TS, Souza ST, Gomes JP, Silva KM \& Santos KF (2012) Floristic composition and phytogeography of the tree component of Araucaria Forest fragments in Southern Brazil. Brazilian Journal of Botany 35: 145-157. doi $<$ http:// dx.doi.org/10.1590/S0100-84042012000200004>.

Koehler A, Galvão F \& Longhi SJ (2002) Floresta ombrófila densa altomontana: aspectos florísticos e estruturais de diferentes trechos na Serra do Mar, PR. Ciência Florestal, Santa Maria 12: 27-39.

Landrum LR (1981) A monograph of the genus Myrceugenia (Myrtaceae). Flora Neotropica 29. The New York Botanical Garden, New York. 135p.

Landrum LR (1986) Campomanesia, Pimenta, Blepharocalyx, Legrandia, Acca, Myrrhinium, and Luma (Myrtaceae). Flora Neotropica 45. The New York Botanical Garden, New York. 178p.

Landrum LR \& Kawasaki ML (1997) The genera of Myrtaceae in Brazil: an illustrated synoptic treatment and identification keys. Brittonia 49: 508536. doi <http://dx.doi.org/10.2307/2807742>.

Legrand CD (1962) El genero Calyptranthes en el Brasil Austral. Lilloa 31: 183-206.

Legrand CD \& Klein RM (1967) Mirtáceas: Gomidesia. In: Reitz R (org.) Flora Ilustrada Catarinense, Itajaí. Pp. 1-44.

Legrand CD \& Klein RM (1969a) Mirtáceas: Eugenia. In: Reitz R (org.) Flora Ilustrada Catarinense, Itajaí. Pp. 45-216.

Legrand CD \& Klein RM (1969b) Mirtáceas: Myrcia. In: Reitz R (org.) Flora Ilustrada Catarinense, Itajaí. Pp. 217-330.

Legrand CD \& Klein RM (1970) Mirtáceas: Myrceugenia. In: Reitz R (org.) Flora Ilustrada Catarinense, Itajaí. Pp. 331-454.

Legrand CD \& Klein RM (1971a) Mirtáceas: Marlierea. In: Reitz R (org.) Flora Ilustrada Catarinense, Itajaí. Pp. 455-488.

Legrand CD \& Klein RM (1971b) Mirtáceas: Calyptranthes. In: Reitz R (org.) Flora Ilustrada Catarinense, Itajaí. Pp. 489-552.

Legrand CD \& Klein RM (1972) Mirtáceas: Calycorectes. In: Reitz R (org.) Flora Ilustrada Catarinense, Itajaí. Pp. 553-570.

Legrand CD \& Klein RM (1977) Mirtáceas: Campomanesia, Feijoa, Britoa, Myrrhinium, Hexachlamys, Siphoneugena, Myrcianthes, Neomitranthes, Psidium. In: Reitz R (org.) Flora Ilustrada Catarinense, Itajaí. Pp. 571-730. 
Legrand CD \& Klein RM (1978) Mirtáceas: Myrciaria, Pseudocaryophyllus, Blepharocalyx; espécies suplementares, espécies cultivadas, generalidades: chave de gêneros. Literatura. Conspecto geral das Mirtáceas. Índice. In: Reitz R (org.) Flora Ilustrada Catarinense, Itajaí. Pp. 571-730.

Lucas E, Belsham SR, Lughadha EN, Orlovich DA, Sakuragui CM, Chase MW \& Wilson PG (2005) Phylogenetic patterns in the fleshy-fruited Myrtaceae, preliminary molecular evidence. Plant Systematics and Evolution 251: 35-51. doi <http:// dx.doi.org/10.1007/s00606-004-0164-9>.

Lucas E, Harris SA, Mazine FF, Belsham SR, Nic Lughadha EM, Telford A, Gasson PE \& Chase MW (2007) Suprageneric phylogenetics of Myrteae, the generically richest tribe in Myrtaceae (Myrtales). Taxon 56: 1105-1128.

Martini AMZ, Fiaschi P, Amorim AM \& Paixão JL (2007) A hot-point within a hot-spot: a high diversity site in Brazil's Atlantic forest. Biodiversity and Conservation 16: 3111-3128. doi <http://dx.doi. org/10.1007/s10531-007-9166-6>.

Martins-Ramos D, Chaves CL, Roseli L, Bortoluzzi C \& Mantovani A (2011) Florística de floresta ombrófila mista altomontana e de campos em Urupema, Santa Catarina, Brasil. Revista Brasileira de Biociências 9: 156-166.

Mattos JR (1957) Notas preliminares sobre as Mirtáceas de São Joaquim (Santa Catarina). Sellowia 8: 354366.

McVaugh R (1968) The genera of american Myrtaceae: an interim report. Taxon 17: 354-418.

Meireles LD, Shepherd GJ \& Kinoshita LS (2008) Variações na composição florística e na estrutura fitossociológica de uma floresta ombrófila densa alto-montana na Serra da Mantiqueira, Monte Verde, MG. Revista Brasileira de Botânica 31: 559-574.

Ministério do Meio Ambiente (2017) Secretaria de Biodiversidade e Florestas, Departamento de Áreas Protegidas. Cadastro Nacional de Unidades de Conservação. Available at $<$ http://sistemas.mma. gov.br/cnuc/index.php?ido=relatorioparametrizado. exibeRelatorio\&relatorioPadrao $=$ true $\&$ idUc $=165>$. Access on 4 March 2017.

Murillo-A J, Stuessy TF \& Ruiz E (2016) Explaining disjunct distributions in the flora of southern South America: evolutionary history and biogeography of Myrceugenia (Myrtaceae). Journal of Biogeography 43: 979-990. doi <http://dx.doi.org/10.1111/ jbi.12702>.

Myers N (1988) Threatened biotas: "hot spots" in tropical forests. Enviromentalist 8: 187-208. doi: <http:// dx.doi.org/10.1007/BF02240252>.

Nic Lughadha EN (1997) Systematic studies in Gomidesia O.Berg (Myrtaceae). University of Saint Andrews, Fife. 503p.
Oliveira-Filho AT (2009) Classificação das fitofisionomias da América do Sul Cisandina tropical e subtropical: proposta de um novo sistema prático e flexível ou uma injeção a mais de caos? Rodriguésia 60 : 237-258.

Olson DM, Dinerstein E, Wikramanayake ED, Burgess ND, Powell GVN, Underwood EC, D'Amico JA, Itoua I, Strand HE, Morrison JC, Loucks CJ, Allnutt TF, Ricketts TH, Kura Y, Lamoreux JF, Wettengel WW, Hedao P, Kassem KR (2001) Terrestrial ecoregions of the world: a new map of life on Earth. Bioscience 51: 933-938.

Peel MC, Finlayson BL \& Mcmahon TA (2007) Updated world map of the Köppen-Geiger climate classification. Hydrology and Earth System Sciences 11: 1633-1644. doi: <http://dx.doi. org/10.5194/hess-11-1633-2007>.

Pereira-Silva EFL, Hardt E \& Francisco CES (2007) Caracterização florística da vegetação lenhosa de um fragmento urbano de Floresta Ombrófila Mista Alto Montana, Campos do Jordão, SP. HOLOS Environment 7: 154-170.

Proença C (1990) A revision of Siphoneugena Berg. Edinburgh Journal of Botany 47: 239-271. doi $<$ https://doi.org/10.1017/S0960428600003401>.

Radford AWC, Dickinson JR \& Massey CR Bell (1976) Vascular plant systematics. Harper and Row, New York. 891p.

Rezende VL, Oliveir-Filho AT, Eisenlohr PV, Kamino LHY, Vibrans AC (2015) Restricted geographic distribution of tree species calls for urgent conservation efforts in the Subtropical Altantic Forest. Biodivesity and Conservation 24: 10571071. doi <http://dx.doi.org/10.1007/s10531-0140721-7>.

Thiers B [continuously updated] Index Herbariorum: a global directory of public herbaria and associated staff. New York Botanical Garden's Virtual Herbarium. Available at $<$ http://sweetgum.nybg. org/science/ih/>. Access on 5 March 2017.

Thornhill AH, Ho SYW, Külheim C \& Crisp MD (2015) Interpreting the modern distribution of Myrtaceae using a dated molecular phylogeny. Molecular Phylogenetics and Evolution 93: 29-43.

Vasconcelos TNC, Proença CEB, Ahmad B, Aguilar DS, Aguilar R, Amorim BS, Campbell K, Costa IR, De-Carvalho PS, Faria JEQ, Giaretta A, Kooij PW, Lima DF, Mazine FF, Peguero B, Prenner G, Santos MF, Soewarto J, Wingler A \& Lucas EJ (2017) Myrteae phylogeny, calibration, biogeography and diversification patterns: increased understanding in the most species rich tribe of Myrtaceae. Molecular Phylogenetics and Evolution 109: 113-137. doi $<$ http://dx.doi.org/10.1016/j.ympev.2017.01.002>.

Vieira FCS (2010) Myrtaceae Juss. no Alto Quiriri, Garuva, Santa Catarina, Brasil. Universidade de São Paulo, São Paulo. 79p. 
Vianna LFN, Silva EB, Massignam AM \& Oliveira SN (2015) Aplicação de descritores de heterogeneidade ambiental na seleção de áreas para sistemas de parcelas amostrais: um estudo de caso para a determinação de hotspots potenciasis de biodiversidade. Geografia, Rio Claro 40: 211-239.

WCSP (2018) World Checklist of Selected Plant Families. Royal Botanic Gardens, Kew. Available at $<$ http://wcsp.science.kew.org/>. Access on 9 May 2018.

Wilson PG, O’Brien MM, Gadek PA \& Quinn CJ (2001) Myrtaceae revisited: a reassessment of infrafamilial groups. American Journal of Botany 88: 2013-2025. Wilson PG, O'Brien MM, Heslewood MM \& Quinn CJ (2005) Relationships within Myrtaceae sensu lato based on a matK phylogeny. Plant Systematics and Evolution 251:3-19. doi < http://dx.doi.org/10.1007/ s00606-004-0162-y>.

Wilson PG (2011) Myrtaceae. In: Kubitzki K (ed.) The families and genera of vascular plants, flowering plants, Eudicots, Sapindales, Cucurbitales, Myrtaceae Vol. X. Springer Verlag, Berlin, Heidelberg. Pp. 212-271. 